\title{
Justifying Gender-Based Affirmative Action under United States $v$. Virginia's "Exceedingly Persuasive Justification" Standard
}

\author{
Jason M. Skaggs $\dagger$
}

While affirmative action has been a hot topic over the course of the past decade, much of the commentary and litigation associated with the issue has involved race-based programs. In fact, the Supreme Court has never examined a gender-based affirmative action program under the Equal Protection Clause. This lack of guidance has resulted in a split among the federal circuit courts of appeals with regard to the appropriate level of scrutiny to be applied to such programs. This Comment addresses this circuit split in light of the Supreme Court's important decision in United States v. Virginia, 116 S. Ct. 2264 (1996), which in its result opened the doors of the Virginia Military Institute to women. This Comment concludes that the Supreme Court mandated that courts apply a new "exceedingly persuasive justification" level of scrutiny to all gender-based classifications, including gender-based affirmative action programs. Finally, this Comment describes the requirements a genderbased affirmative action program must meet in light of this new standard.

\section{INTRODUCTION}

The United States Supreme Court's decision in United States $v$. Virginia, ${ }^{1}$ which opened the doors of the Virginia Military Institute (VMI) to women, has generated a great deal of controversy regarding its

Copyright $\odot 1998$ California Law Review, Inc.

$\dagger$ Law Clerk to the Honorable Procter Hug, Jr., Chief Judge, U.S. Court of Appeals for the Ninth Circuit; J.D., Boalt Hall School of Law (University of California at Berkeley), 1998; B.A., Duke University, 1994. Thanks to Profcssors John Yoo and Linda Krieger for their helpful suggestions. Thanks also to the members of the California Law Review, particularly Doni Gewirtzman, for their suggestions and thorough editing. All remaining mistakes and omissions are entirely my own. Finally, special thanks to my parents, my grandparents, and, of course, Ryen and Zack, for their love and support.

1. 116 S. Ct. 2264 (1996). 
effect on the standard of review under the Equal Protection Clause for many different types of gender-based programs and laws. One interpretation of the opinion is that gender-based classifications should be analyzed under the same "intermediate scrutiny" standard which the Court has applied for the last twenty years. ${ }^{2}$ Another position, set forth in Justice Scalia's dissent, suggests that the Virginia Court mandated that lower courts subject gender-based classifications to the same "strict scrutiny" standard which has been reserved for racial classifications. ${ }^{3}$ Still others argue that Virginia has created a new standard for gender-based classifications that falls somewhere between intermediate and strict scrutiny. ${ }^{4}$

The confusion associated with Virginia is exacerbated in the context of gender-based affirmative action, an issue which the Supreme Court has never examined under the Equal Protection Clause. This lack of direct Supreme Court guidance has forced the lower federal courts to look to other case law to determine how to evaluate gender-based affirmative action programs. The search has resulted in a circuit split on the proper level of scrutiny. Some courts analyze the programs under the intermediate scrutiny approach developed for examining gender classifications. ${ }^{5}$ Others employ the more demanding strict scrutiny standard of analysis found in the Court's precedents on race-based

2. See, e.g., Engineering Contraetors Ass'n v. Metropolitan Dade County, 122 F.3d 895, 908 (11th Cir. 1997) (finding that "intermediate scrutiny remains the applicable constitutional standard in gender discrimination cases"), cert. denied, 118 S. Ct. 1186 (1998); Cohen v. Brown Univ., 101 F.3d $155,183 \mathrm{n.22}$ (1st Cir. 1996) (finding that Virginia "adds nothing to the analysis of ... gcnder-based classifications that has not been part of that analysis since 1979").

3. See Virginia, 116 S. Ct. at 2294 (Scalia, J., dissenting) (noting that the government urged the Court to adopt strict scrutiny for gender classifications, and that the Court effectively accepted this argument); see also Candace Saari Kovacic-Fleischer, United States v. Virginia's New Gender Equal Protection Analysis with Ramifications for Pregnancy, Parenting, and Title VII, 50 VAND. L. REV. 845, 883 (1997) (arguing that the Court has elevated gender equal protection analysis to the level of the least-restrictive-means analysis of strict scrutiny); Steven A. Delchin, Comment, United States v. Virginia and Our Evolving "Constitution": Playing Peek-A-Boo With the Standard of Scrutiny for SexBased Classifications, 47 CASE W. REs. L. REv. 1121 (1997) (arguing that the decision represents the Court's final step to strict scrutiny for sex-based classifications).

4. See, e.g., Cohen, 101 F.3d at 191 (Torruella, C.J., dissenting) (stating that the Court "appears to have elevated the test applicable to sex discrimination cases to require an "exceedingly persuasive justification"'); Jeffrey A. Barnes, Casenote, The Supreme Court's "Exceedingly [Un]persuasive" Application of Intermediate Scrutiny in United States v. Virginia, 31 U. Rich. L. REv. 523 (1997); Christina Gleason, Comment, United States v. Virginia: Skeptical Scrutiny and the Future of Gender Discrimination Lanv, 70 ST. JohN's L. REv. 801 (1996); Karen Lazarus Kupetz, Casenote, Equal Benefits, Equal Burdens: "Skeptical Scrutiny" for Gender Classifications After United States v. Virginia, 30 Loy. L.A. L. Rev. 1333 (1997); Kathryn A. Lee, Casenote, Intermediate Review "With Teeth" in Gender Discrimination Cases: The New Standard in United States v. Virginia, 7 Temp. Pol. \& Civ. RTs. L. REv. 221 (1997).

5. The Third, Ninth, Tenth, and Eleventh Circuits use this approach. See infra notes 40-43. 
affirmative action. ${ }^{6}$ The fact that the Court has not developed precise requirements for each level of scrutiny only compounds the problem.

This Comment seeks to clarify the standard for evaluating genderbased classifications in light of the Virginia opinion, to use this standard to resolve the split among the lower courts, and to determine the requirements for justifying gender-based affirmative action plans. Part I provides the framework for this discussion by briefly summarizing the Court's approach to gender-based classifications, and to race-based affirmative action. This Part also describes the basis for the circuit court split on the standard of analysis for gender-based affirmative action programs. Finally, it illustrates the impact of this split by outlining the factual predicates necessary to justify these programs under each level of scrutiny.

Part II examines the effect of the Virginia opinion on gender-based classifications. This Comment argues that when Virginia is viewed as part of a doctrinal progression from the Court's earlier decisions in Mississippi University for Women v. Hogan ${ }^{7}$ and J.E.B. v. Alabama ex rel. T.B. ${ }^{8}$ the result is an "exceedingly persuasive justification" standard which is firmly rooted in the Court's jurisprudence. This standard is more demanding than the intermediate scrutiny used for gender-based classifications since 1976, but less stringent than strict scrutiny.

Parts III and IV examine the impact of the Virginia decision on gender-based affirmative action programs. Part III concludes that the circuit court split should be resolved by subjecting all gender-based classifications, including gender-based affirmative action, to the "exceedingly persuasive justification" standard. This solution is grounded in Supreme Court case law, and provides the most effective resolution of the paradoxes associated with gender-based affirmative action. Finally, Part IV sets forth the factual predicate implicated by this new standard. Genderbased affirmative action plans are permissible when their purpose is to remedy societal discrimination in a narrowly defined economic sphere. 9 This asserted purpose must be supported by persuasive evidence, and the plan must be closely related to this purpose.

6. The Sixth Circuit and the Supreme Court of Georgia adhere to this approach. See infra notes 38-39.

7. 458 U.S. $718(1982)$.

8. 511 U.S. 127 (1994).

9. This Comment's discussion of gender-based affirmative action is limited to the type of government contracting programs discussed in Supreme Court cases such as Adarand Constructors, Inc. v. Peña, 515 U.S. 200 (1995), and City of Richmond v. J.A. Croson Co., 488 U.S. 469 (1989). While much of this Comment's analysis applies to educational or employment affirmative action programs, a specific discussion of these areas of concern is beyond this Comment's scope. 
Analysis of Gender-Based Affirmative Action under the EQual Protection Clause

\section{A. Analyzing Equal Protection Problems: Three Levels of Scrutiny}

Equal Protection challenges can trigger different degrees of judicial scrutiny depending upon the nature of the statutory classification at issue. The highest level of scrutiny, labeled strict scrutiny, is applied to classifications based on race and national origin. ${ }^{10}$ In order to survive this standard, the statute must be narrowly tailored to serve a compelling governmental interest. " Conversely, the lowest level of scrutiny, rational basis, is applicd to all non-suspect classifications and requires only that the statute be rationally related to a legitimate governmental interest. ${ }^{12}$ This so-called traditional approach has been applied to general economic and social welfare regulation since the late $1930 \mathrm{~s}^{13}$

Gender-based classifications were analyzed under this rational basis standard until $1971,{ }^{14}$ when the Court announced its decision in Reed $v$. Reed. ${ }^{15}$ In Reed, the Court struck down a statute which gave preference to males in the administration of intestate estates. It also indicated that it would subject gender classifications to a higher level of scrutiny by requiring that the relationship between the classification and the statutory objective be "fair and substantial" instead of merely "rationally related."16 Two years later, Justice Brennan's opinion in Frontiero $v$. Richardson ${ }^{17}$ built upon Reed. He applied strict scrutiny to invalidate a rule which automatically entitled servicemen to claim their wives as dependents, but forced servicewomen to show actual dependence by their husbands. ${ }^{18}$ However, Justice Brennan's opinion only garnered four votes for the application of strict scrutiny to gender-based classifications, ${ }^{19}$ and the proposition has never commanded a majority of the Court.

10. See United States v. Virginia, 116 S. Ct. 2264, 2275 n.6 ("The Court has thus far reserved most stringent judieial serutiny for classifieations based on race or national origin ...."); Clark v. Jeter, 486 U.S. 456, 461 (1988).

11. See Adarand Constructors, Inc. v. Peña, 515 U.S. 200, 235 (1995); City of Cleburne v. Cleburne Living Center, Inc., 473 U.S. 432,440 (1985).

12. See Romer v. Evans, 517 U.S. 620,627 (1996); Clark, 486 U.S. at 461; City of Cleburne, 473 U.S. at 440 .

13. See William B. Lockhart et al., The american Constitution 1148 (8th ed. 1996).

14. See laurence H. Tribe, american Constitutional Law $\$ 16-25$, at 1559 (2d ed. I988).

I5. 404 U.S. 71 (1971).

16. See id. at 76-77.

17. 4II U.S. 677 (1973) (plurality opinion).

18. See id. at 688 .

19. Justice Powell's concuring opinion, joined by Chief Justice Burger and Justice Blackmun, agreed that the statutes constituted unconstitutional discrimination against servicewomen, but found it "unnecessary for the Court in this case to characterize sex as a suspect classification." Id. at 691-92 
Instead, since its 1976 decision in Craig v. Boren, ${ }^{20}$ the Court has recognized an intermediate level of scrutiny as the proper standard of analysis for gender classifications. ${ }^{21}$ This standard requires that gender classifications have a substantial relationship to important governmental objectives. ${ }^{22}$ However, the Court's decisions in Mississippi University for Women v. Hogan, ${ }^{23}$ J.E.B. v. Alabama ex. rel. T.B., ${ }^{24}$ and United States $v$. Virginia ${ }^{25}$ have transformed this standard into a more demanding inquiry. ${ }^{26}$

\section{B. Affirmative Action and Equal Protection}

Although the general topic of affirmative action has attracted a great deal of attention, case law and commentary have primarily focused on race-based programs. The Supreme Court has never analyzed a gender-based affirmative action program under the Equal Protection Clause, ${ }^{27}$ and the most significant recent affirmative action cases, City of Richmond v. J.A. Croson Co. ${ }^{28}$ and Adarand Constructors, Inc. v. $P e \tilde{n} a{ }^{29}$ concentrated on race-based programs without addressing gender-based programs. ${ }^{30}$ However, because Croson and Adarand are such significant cases with regard to the constitutionality of race-based affirmative action, they have heavily influenced gender-based affirmative action. ${ }^{31}$

In 1989, a majority of the Court in Croson held that state and local race-based affirmative action programs are subject to strict

(Powell, J., concurring). Instead, Powell wrote that "we can and should decide this case on the authority of Reed and reserve for the future any expansion of its rationale." Id. at 692 (Powell, J., concurring). Justice Stewart wrote a separate concurrence, citing Reed in agreeing that the statutes constituted an invidious discrimination in violation of the Constitution, but he did not set forth his view as to the proper standard for review. Id. at 691 (Stewart, J., concurring).

20. 429 U.S. 190 (1976).

21. See Gerald Gunther, Constitutional Law 605 (12th ed. 1991).

22. See, e.g., Craig v. Boren, 429 U.S. 190, 197 (1976); City of Cleburne v. Cleburne Living Center, Inc., 473 U.S. 432,44 I (1985).

23. 458 U.S. 718 (1982).

24. 51 I U.S. 127 (1994).

25. 116 S. Ct. 2264 (1996).

26. See infra Part Il.

27. While Johnson v. Transportation Agency, 480 U.S. 616 (1987), did deal with such a program, the analysis was based on Title VII. As the Court recognized, the obligations of a public employer under Title VIl and under the Constitution with regard to an affirmative action plan are not identical. See id. at 627 n. 6 .

28. 488 U.S. 469 (1989).

29. 515 U.S. 200 (1995).

30. Adarand recognized that one of the rcgulations involved presumed that women, like racial minorities, are socially and economically disadvantaged, see id. at 208, and cited to cases dealing with gender discrimination. See $i d$. at 217 . Howcver, the analysis and conclusion of the opinion are confined to racial classifications. See id. at 218-27.

3I. See, e.g., cases cited infra notes 38-44. 
scrutiny..$^{32}$ The Court deemed this demanding standard necessary to "smoke out" racial classifications based upon "illegitimate notions of racial inferiority" or "illegitimate racial prejudice or stereotype." Moreover, the opinion noted that "[c]lassifications based on race carry a danger of stigmatic harm."34 The result of Croson was that if a local governmental body wanted to pursue a race-conscious remedial plan, it had to show either "prior discrimination by the governmental unit involved"35 or that it was a passive participant in a system of racial exclusion practiced by elements of the local industry. ${ }^{36}$ In Adarand, the Court extended this standard to federal race-based programs, holding that courts should apply strict scrutiny to all federal, state, and local race-based classifications, including affirmative action programs. ${ }^{37}$

\section{Gender-Based Affirmative Action:}

\section{The Lower Court Split as to the Appropriate Level of Scrutiny}

Because the only guidance the Supreme Court has provided for deciding affirmative action cases comes from opinions analyzing racebased programs under strict scrutiny, the proper level of scrutiny for analyzing gender-based affirmative action is unclear. The question the Court has left open is whether Croson and Adarand mean that all affirmative action programs are subject to strict scrutiny, or that affirmative action is subject to the same level of scrutiny as the classification involved. Before the Virginia decision, when intermediate scrutiny was still understood as the proper level of analysis for gender-based classifications, the lower courts were split on this issue. The Sixth Circuit, ${ }^{38}$ as well as the Georgia Supreme Court, ${ }^{39}$ subjected gender-based affirmative action programs to strict scrutiny while analyzing all other gender-based

32. See Croson, 488 U.S. at 493-94. The section of Justiee O'Connor's opinion which reaches this conclusion, Part IIl-A, was officially joined by only Justices White, Rehnquist, and Kennedy. However, while writing separately, Justice Scalia indicated that he agreed with the "conclusion that strict scrutiny must be applied to all governmental classification by race." Id. at 520 (Scalia, J., concurring).

33. Id. at 493 .

34. Id.

35. Id. at 492 (quoting Wygant v. Jackson Bd. of Educ., 476 U.S. 267, 274 (1986)).

36. See id. An example of this "passive participant" concept would be a case in which a city faced with evidence that non-minority contractors were systematically excluding minority businesscs from subcontracting opportunities had done nothing to remedy the problem. In such a case, the city could take action to end the discriminatory exclusion. See id. at 509.

37. See Adarand Constructors, Inc. v. Peña, 515 U.S. 200, 225-27 (1995) (overruling Metro Broadcasting, Inc. v. FCC, 497 U.S. 547 (1990)).

38. See Brunet v. City of Columbus, I F.3d 390, 403-04 (6th Cir. I993); Vogel v. City of Cincinnati, 959 F.2d 594 (6th Cir. 1992); Long v. City of Saginaw, 9I I F.2d II92 (6th Cir. 1990); Conlin v. Blanchard, 890 F.2d 8 II (6th Cir. 1989).

39. See American Subcontractors Ass'n v. City of Atlanta, 376 S.E.2d 662, 664 (Ga. 1989) (applying strict scrutiny to program favoring minority and female-owned enterprises in awarding city contracts). 
classifications under intermediate scrutiny. In contrast, the Third, ${ }^{40}$ Ninth, ${ }^{41}$ Tenth, ${ }^{42}$ and Eleventh Circuits ${ }^{43}$ used intermediate scrutiny to analyze all gender-based classifications, including affirmative action. The remaining circuits have not taken a definitive position on the matter, although the Seventh Circuit ${ }^{44}$ has indicated that it may also apply the intermediate scrutiny standard to all gender-based classifications.

A primary reason that the proper level of scrutiny for gender-based affirmative action programs is such a difficult issue is that there are troubling paradoxes associated with both approaches. The application of intermediate scrutiny to gender-based affirmative action programs means that race-based affirmative action is subject to a higher level of constitutional scrutiny. Thus, it is more likely that a race-based remedial program will be invalidated than an affirmative action program based on gender, even though racial minorities are meant to receive a higher level of protection from discrimination than women. ${ }^{45} \mathrm{~A}$ related anomaly is that white men have greater protection against reverse discrimination through race-based affirmative action programs than women have against gender discrimination..$^{46}$ For example, a race-based affirmative action program challenged by a white male will be subject to the demanding strict scrutiny standard, while government sponsored discrimination against women will be reviewed under the more deferential intermediate level of scrutiny. Such a result is at odds with the Court's emphasis on historic discrimination against protected groups as a justification for invoking heightened scrutiny. ${ }^{47}$

However, the Sixth Circuit's application of strict scrutiny to gender-based affirmative action while analyzing other gender-based classifications under intermediate scrutiny also presents a problem. Under

40. See Contractors Ass'n v. City of Phila., 6 F.3d 990, 1000-01 (3d Cir. 1993).

41. See Coral Constr. Co. v. King County, 941 F.2d 910, 930 (9th Cir. 1991).

42. See Concrete Works, Inc. v. City \& County of Denver, 36 F.3d 15I3, 1519 (10th Cir. 1994).

43. See Engineering Contractors Ass'n v. Metropolitan Dade County, 122 F.3d 895, 907-08 (11th Cir. 1997), cert. denied, 118 S. Ct. 1186 (1998); Ensley Branch, NAACP v. Seibels, 31 F.3d 1548 (11th Cir. 1994). Engineering Contractors was decided after Virginia, but the Eleventh Circuit in that case incorrectly applied intermediate scrutiny instead of the "exceedingly persuasive justification" standard set forth by the Court in Virginia. See infra Part II; see also infra note 210.

44. See Milwaukee County Pavers Ass'n v. Fieldler, 922 F.2d 419 (7th Cir. 1991). While the court stated that "Croson is about favoritism toward racial and ethnic groups, not about favoritism toward women.... so maybe the state's program, insofar as it favors women, is not controlled by Croson," it found that the statc had waived this argument and therefore the question was not addressed. Id. at 422.

45. See Deborah L. Brake, Sex as a Suspect Class: An Argument for Applying Strict Scrutiny to Gender Discrimination, 6 SETON Hall Const. L.J. 953, 961 (1996); see also Adarand Constructors, Inc. v. Peña, 515 U.S. 200, 247 (1995) (Stevens, J., dissenting) (identifying the paradox and noting that "the primary purpose of the Equal Protection Clause was to end discrimination against the former slaves").

46. See Brake, supra note 45 , at 961 .

47. See id. 
the strict scrutiny approach, it is easier for the government to discriminate against women than to remedy discrimination against them. ${ }^{48}$

Thus, the Supreme Court's failure to define the appropriate level of scrutiny for gender-based affirmative action, as well as the inherent paradoxes associated with the approaches adopted by the lower courts, have left this area of the law in disarray. As discussed below, ${ }^{49}$ however, the Virginia opinion provides an appealing resolution of this problem.

D. Analyzing Affirmative Action under Strict Scrutiny versus Intermediate Scrutiny: The Different Requirements Associated with Each Standard

The choice between strict and intermediate scrutiny is quite significant in the context of affirmative action, as it is much easier to justify an affirmative action plan under intermediate scrutiny than strict scrutiny. As noted above, intermediate scrutiny requires the classification to be substantially related to an important governmental objective, ${ }^{50}$ while strict scrutiny requires a statute to be narrowly tailored to serve a compelling government interest. ${ }^{51}$ The following discussion contrasts the factual predicates necessary to justify affirmative action under each standard, providing the foundation for a subsequent analysis of the requirements for gender-based affirmative action programs in light of the Supreme Court's decision in United States v. Virginia. ${ }^{52}$

\section{Justifying Affirmative Action under Strict Scrutiny}

a. Demonstrating a Compelling Government Interest: Discrimination

by a Specific Entity Supported by a "Strong Basis in Evidence"

Under the Court's strict scrutiny analysis, a government entity can only justify an affirmative action program by asserting that its purpose is to remedy past or present discrimination by that specific governmental unit. ${ }^{53}$ Therefore, a generalized assertion that there has been past discrimination in an entire industry will not be enough to justify a program under strict scrutiny. ${ }^{54}$ The government must have actively discriminated in its award of contracts or employment or have been a passive participant in a system of racial exclusion practiced by elements of a local industry. ${ }^{55}$

\footnotetext{
48. See id.

49. See infra Part III.

50. See supra note 22 and accompanying text.

5I. See supra note II and accompanying text.

52. II6 S. Ct. 2264 (I996).

53. See City of Richmond v. J.A. Croson Co., 488 U.S. 469, 492 (1989).

54. See id. at 498.

55. See id. at 492 .
} 
In order to uphold an affirmative action program under strict scrutiny, there must exist a "strong basis in evidence" of past discrimination by the specific entity to support the conclusion that remedial action is necessary. ${ }^{56}$ The most probative type of evidence seems to be statistical data showing "gross statistical disparities between the proportion of minorities hired ... and the proportion of minorities willing and able to do the work. ${ }^{157}$ In government contracting cases, this is often shown through the use of a disparity index, which is a comparison between the share of contracts awarded to minority contractors and the percentage of qualified minority owned firms in the local population that do such work..$^{58}$ In addition, while the combination of "convincing anecdotal and statistical evidence is potent, ${ }^{159}$ anecdotal evidence, by itself, will rarely suffice to justify an affirmative action program evaluated under strict scrutiny. ${ }^{60}$

\section{b. Showing That a Program Is Narrowly Tailored to the Compelling Government Interest}

Croson sets forth four general guidelines to determine whether an affirmative-action plan is narrowly tailored to the asserted government interest in remedying past discrimination..$^{61}$ Based on these guidelines, the Third and Eleventh Circuits have developed four-factor tests to evaluate whether affirmative action programs are narrowly tailored. ${ }^{62}$ One consideration is whether the government has first considered raceneutral means, such as enhanced access to capital and relaxation of

56. See id. at 500 .

57. Engineering Contractors Ass'n v. Metropolitan Dade County, 122 F.3d 895, 907 (11th Cir. 1997), cert. denied, 118 S. Ct. 1186 (1998) (quoting Ensley Branch, NAACP v. Seibels, 31 F.3d 1548, 1565 (11 th Cir. 1994)); see also Contractors Ass'n v. City of Phila., 6 F.3d 990, 1004 (3d Cir. 1993).

58. See Contractors Ass'n, 6 F.3d at 1005.

59. Id. at 1003 (quoting Coral Constr. Co. v. King County, 941 F.2d 910, 919 (9th Cir. 1991)).

60. For example, while the Third Circuit allows that "anecdotal evidence alone may, in an exceptional case, be so dominant or pervasive that it passes muster under Croson," Contractors Ass'n, 6 F.3d at 1003, the Ninth Circuit indicates that "anecdotal evidence ... rarely, if ever, can ... show a systemic pattern of discrimination necessary for the adoption of an affirmative action plan," Coral Constr., 941 F.2d at 919, and the Eleventh Circuit says that "only in the rare case will anecdotal evidence suffice standing alone." Engineering Contractors, 122 F.3d at 925. See also Concrete Works, Inc. v. City \& County of Denver, 36 F.3d 1513, 1521 (10th Cir. 1994) ("[W]e deem anecdotal evidence ... a appropriate supplementary evidence in our strict scrutiny calculus.") (emphasis added). These statements also seem consistent with O'Connor's plurality in Croson, which noted that "evidence of a pattern of individual discriminatory acts can, if supported by appropriate statistical proof, lend support to a local goverument's determination that broader remedial relief is justified." Croson, 488 U.S. at 509 (emphasis added).

61. See Croson, 488 U.S at 507-08. The Court in Croson did not explicitly set forth a method for assessing whether a program is narrowly tailored, noting that in that case "it is almost impossible to assess whether the Richmond Plan is narrowly tailored to remedy past discrimination since it is not linked to identified discrimination in any way." Id. at 507.

62. See Engineering Contractors, 122 F.3d at 927 (citing Ensley Branch, NAACP v. Seibels, 31 F.3d 1548, 1569 (11th Cir. 1994)); Contractors Ass'n, 6 F.3d at 1008. 
bonding requirements, and found them ineffective. ${ }^{63}$ Thus, "preferences ... must be only a 'last resort' option." Another consideration is the flexibility and duration of the relief, including the availability of waiver provisions or other means of affording individualized treatment. ${ }^{65}$ The relationship of numerical goals to the relevant labor market constitutes a third consideration in examining affirmative action programs, ${ }^{66}$ and "special vigilance is required against unyielding racial quotas." ${ }^{967}$ Finally, the courts must examine the impact of the relief on the rights of innocent third parties. ${ }^{68}$

\section{Justifying Affirmative Action under Intermediate Scrutiny \\ a. Demonstrating an Important Government Interest: Societal Discrimination in the Relevant Economic Sphere Supported by Sufficient Probative Evidence}

While strict scrutiny requires the government to prove its own past discrimination to justify an affirmative action program, intermcdiate scrutiny is much less demanding. The few federal circuit courts that have addressed the issue indicate that remedying societal discrimination is a sufficient justification under intermediate scrutiny, as long as the discrimination affected the economic sector targeted by the program. ${ }^{69}$

Two federal appellate courts have attempted to determine the proper standard for examining the sufficiency of evidence under intermediate scrutiny. ${ }^{70}$ The Third Circuit in Contractors Ass' $n$ v. City of

63. See Contractors Ass'n, 6 F.3d at 1008; see also Engineering Contractors, 122 F.3d at 927 (quoting Ensley Branch, 31 F.3d at 1569) (considering the necessity for the relief and the efficacy of alternative remedies).

64. Engineering Contractors, at 122 F.3d at 926 (quoting Hayes v. North State Law Enforcement Officers Ass'n, 10 F.3d 207, 217 (4th Cir. 1993)); see also Croson, 488 U.S. at 519 (Kennedy, J., concurring in part and concurring in the judgment).

65. See Engineering Contractors, 122 F.3d at 927 (quoting Ensley Branch, 31 F.3d at 1569); Coniraciors Ass'n, 6 F.3d at 1008.

66. See Engineering Contractors, 122 F.3d at 927 (quoting Ensley Branch, 31 F.3d at 1569); Contractors Ass'n, 6 F.3d at 1008 .

67. Ensley Branch, 31 F.3d at 1569.

68. See Engineering Contractors, 122 F.3d at 927 (quoting Ensley Branch, 31 F.3d at 1569). The fourth factor set forth in Contraclors Ass' $n$ is somewhat diffcrent: whether the ordinance applies only to minority businesses who operate in the geographic jurisdiction covered by the ordinance. See Contractors Ass' $n, 6$ F.3d at 1008.

69. See Engineering Contractors, 122 F.3d at 910; Ensley Branch, 31 F.3d at 1580; Coral Constr. Co. v. King County, 941 F.2d 910, 931 (9th Cir. 1991).

70. Another circuit court appeared to require the "strong basis in evidence" associated with strict scrutiny to justify a gender-based program analyzed under intermediate scrutiny. While the Tenth Circuit stated that it would analyze the programs under different standards, it examined the evidence together and seemed to require this strong basis in evidence for both typcs of programs. See Concrete Works, Inc. v. City \& County of Denver, 36 F.3d 1513, 1521, 1522 (10th Cir. 1994). However, bccause the court concluded that the evidence supporting both aspects of the overall affirmative action program was enough to survive a summary judgment motion, it may have felt it redundant to go through the examination again under intermediate scrutiny. 
Philadelphia ${ }^{71}$ concluded that probative evidence was required to support the stated rationale for the gender preference, ${ }^{72}$ and that the city had failed to meet this standard. ${ }^{73}$ This standard provided a starting point for the discussion of sufficiency of evidence in the Eleventh Circuit's recent decision in Engineering Contractors Ass'n v. Metropolitan Dade County. ${ }^{74}$ The appellate court first pointed out that while it agreed with the Third Circuit's holding in Contractors Ass' $n$, the evidence produced in that case was probative. ${ }^{75}$ The Eleventh Circuit resolved this apparent dilemma by announcing a "sufficient probative evidence" standard. ${ }^{76}$ However, the court did little to clarify further what this standard meant; it simply noted that this standard as well as strict scrutiny's "strong basis in evidence" standard "necessarily are tautological when the words alone are considered and must draw meaning from an evolving body of case law that will define them."

In terms of the type of evidence required to meet the government interest prong under intermediate scrutiny, the Contractors Ass' $n$ opinion noted that the Supreme Court's gender-preference cases are inconclusive and are difficult to reconcile on this point. ${ }^{78}$ While the Third Circuit did not explicitly decide the issue, it did indicate that unlike strict scrutiny, defendants may be able to rely solely on anecdotal evidence to justify a plan under intermediate scrutiny. ${ }^{79}$ Similarly, in Coral

71. 6 F.3d 990 (3d Cir. 1993).

72. See id. at 1010 .

73. See id. at 1010-11. In reaching its conclusion, the court first rejected statistics from a city counsel report as well as an affidavit from a woman in the catering business, because they reflected the participation of women in city contracting generally instead of in the relevant economic sector of construction. See id. The court also considered a study which did not contain a disparity index for women-owned construction businesses, as well as one affidavit and a sentence of testimony at a city counsel hearing, but this evidence was rejected as insufficient evidence regarding the construction industry. See id. at 1011.

74. 122 F.3d 895 (1 1th Cir. 1997), cert. denied, 118 S. Ct. 1186 (1998).

75. See id. at 909-10 (explaining that Black's LAW Dictionary defines “"probative evidence' as evidence 'tending to prove' or which 'contributes toward proof').

76. Id. at 910 (emphasis added).

77. Id. The Eleventh Circuit considered several sets of statistics and studies, and found that the only clear disparity that could not be explained existed in one type of construction (out of three) in a single year. See id. at $918,911-24$. Thus, while noting it may not have reached the same conclusion as the district court the Eleventh Circuit concluded that the lower court had not clearly erred in failing to find a sufficient evidentiary foundation for the programs. See id. at 926 .

78. See Contractors Ass'n v. City of Phila., 6 F.3d 990, 1010 (3d Cir. 1993).

79. See id. at 1011 ("Given the absence of probative evidence, the City must rely solely on anecdotal cvidence to establish gender discrimination necessary to support the Ordinance."). Other decisions which involve gender-based affirmative action and consider the issue of anecdotal evidence do not discuss its significance in the intermediate scrutiny context. For example, Engineering Contractors's discussion of anecdotal evidence did not distinguish between its consideration of strict and intermediate scrutiny, and its discussion of the case law is based entirely on cases where the significance of anecdotal evidence is considered in the context of strict scrutiny. See Engineering Contractors, 122 F.3d at 924-26. 
Construction Co. v. King County, ${ }^{80}$ the Ninth Circuit held that the record adequately indicated discrimination against women in the county construction industry despite the absence of statistical evidence. ${ }^{81}$ Therefore, while the issue is certainly not settled, it appears that even a moderate amount of anecdotal evidence may be enough to satisfy the evidentiary burden for gender-based affirmative action under intermediate scrutiny. ${ }^{82}$

\section{b. Showing a Substantial Relation to an Important Government Interest}

The Eleventh Circuit is the only federal court of appeals to describe how to evaluate an affirmative action program under intermediate scrutiny's substantial relationship prong. Its analysis roughly parallels the four-factor test it uses to analyze affirmative action programs under strict scrutiny. ${ }^{83}$

With regard to alternative remedies, in Ensley Branch, NAACP v. Seibels, ${ }^{84}$ the circuit court stated that the goal of eliminating gender discrimination in public employment "requires, at a minimum, the development of gender-neutral selection procedures-whether or not developed in conjunction with a program of [affirmative action] designed to remedy discrimination against women."85 However, it does not appear that other gender-neutral remedies, such as the enhanced access to capital and relaxation of bonding requirements suggested by Croson, need be considered and found ineffective before a gender-based affirmative action program is employed. ${ }^{86}$ In addition, the Eleventh Circuit has stated that the duration of a remedy is important to intermediate as well as strict scrutiny analysis. A court cannot permit "a potentially indefinite cycle of discrimination to continue" because this may "foster the

80. 941 F.2d 910 (9th Cir. 1991).

81. See id. at 932-33. The court supported its conclusion by describing a single affidavit submitted by the female president of an engineering consulting firm. See id. at 933 . The court had previously noted that three affidavits had becn submitted complaining about discrimination against women in the local construction industry. See id. at 917-18.

82. While some anecdotal evidence was offered in Contractors $A s s^{\prime} n$, it appeared to be even weaker than that offered in Coral Construction. Compare supra note 73 with supra note 81 and accompanying text.

83. See supra notes 63-68 and accompanying text. The Eleventh Circuit's discussion of intermediate scrutiny did not mention the fourth factor of strict scutiny analysis-impact of relief on the rights of innocent third parties.

84. 31 F.3d 1548 (11 th Cir. 1994).

85. Id. at 1581.

86. While neither Ensley Branch nor Engineering Contractors explicitly addrcsses the issue, the court in Engineering Contractors implies that gender-ncutral remedies do not need to be considered under intermediate scrutiny. See Engineering Contraetors Ass'n v. Metropolitan Dade County, 122 F.3d 895, 929 (11th Cir. 1997), cert. denied, 118 S. Ct. 1186 (1998) (noting that the government was not required to implement the program only as a last resort). 
misguided belief that women cannot compete on their own."287 Finally, with regard to the numerical goals of a program, a gender-conscious program analyzed under intermediate scrutiny does not need to establish a close tie between its numerical goals to the proportion of qualified women in the market. ${ }^{88}$ However, such goals must be "needed to eradicate lingering effects of discrimination against women."

\section{A Summary of Strict Scrutiny versus Intermediate Scrutiny in the Affirmative Action Context}

As described above, affirmative action programs are much easier to justify under intermediate scrutiny than under strict scrutiny. While strict scrutiny requires that the purpose underlying such programs be to remedy past discrimination by the entity instituting the program, societal discrimination in the relevant economic sphere is a permissible justification under intermediate scrutiny. Moreover, the strong basis in evidence burden required under strict scrutiny ${ }^{90}$ is far more demanding than the probative evidence ${ }^{91}$ or sufficient probative evidence ${ }^{92}$ burdens associated with intermediate scrutiny.

With regard to the relationship prong of the analysis, similar tests are used to examine affirmative action programs. However, the analysis under intermediate scrutiny is considerably more lenient. While preferences under strict scrutiny must be a "last resort" option," tion of gender-neutral remedies does not appear to be required under intermediate scrutiny. Finally, while the duration of the program is important under both standards, strict scrutiny requires a much closer tie between the numerical goals of the program and the relevant labor market than does intermediate scrutiny.

87. Ensley Branch, 31 F.3d at 1581-82.

88. See Engineering Contractors, 122 F.3d at 929 (citing Ensley Branch, 31 F.3d at 1582). But see Back v. Carter, 933 F. Supp. 738, 759 (N.D. Ind. 1996) ("If the interest justifying the classification is discrimination against women attorneys during the election, the classification should be tied to the percentage of women attorneys rather than to attempt to strike simple gender balancing.").

89. Ensley Branch, 31 F.3d at 1582.

90. See City of Richmond v. J.A. Croson Co., 488 U.S. 469, 500 (1989) (citing Wygant v. Jackson Bd. of Educ., 476 U.S. 267, 277 (1986) (plurality opinion)).

91. See Contractors Ass'n v. City of Phila., 6 F.3d 990, 1011 (3d Cir. 1993).

92. See Engineering Contractors, I22 F.3d at 910.

93. Id. at 926 (quoting Hayes v. North State Law Enforcement Officers Ass'n, 10 F.3d 207, 217 (4th Cir. 1993)). 
II

Elevating THE STANDARD OF ANALYSIS FOR GENDER-BASED

Classifications: Hogan, J.E.B., Virginia, and the "ExcEedingly

PERsuasive JustifiCATION" Formulation

The 1996 Supreme Court decision in United States v. Virginia ${ }^{94}$ generated significant controversy and commentary regarding its effect on the standard of review for gender-based classifications. ${ }^{95}$ Commentators and courts have interpreted Virginia in three different ways: (1) intermediate scrutiny continues to apply to gender-based classifications; ${ }^{96}(2)$ gender classifications are subject to strict scrutiny; ${ }^{97}$ and (3) gender classifications are now subject to a level of analysis which falls between strict and intermediate scrutiny. ${ }^{98}$ This Comment, like several other articles on the topic, ${ }^{99}$ concludes that while Virginia does not prescribe strict scrutiny for gender classifications, it does promote a significantly more demanding standard of rcview than traditional intermediate scrutiny. Nevertheless, courts attempting to discern the proper standard of review since Virginia have refused to apply an explicitly higher standard of scrutiny for gender classifications. ${ }^{100}$ While courts are understandably reluctant to employ stricter scrutiny on the basis of one opinion that does not explicitly require it, ${ }^{101}$ this objection loses its force when Virginia is viewcd in terms of a doctrinal progression towards a higher level of scrutiny: from Mississippi University for Women v. Hogan ${ }^{102}$ to J.E.B. v. Alabama ex rel. T.B. ${ }^{103}$ to Virginia. Under this interpretation, this more rigorous standard is firmly rooted in Equal

94. 116 S. Ct. 2264 (1996).

95. See supra notes $2-4$ and accompanying text.

96. See supra note 2.

97. See supra note 3.

98. See supra note 4.

99. See id.

100. See, e.g., Engineering Contractors Ass'n v. Metropolitan Dade County, 122 F.3d 895, 908 (11th Cir. 1997), cert. denied, 118 S. Ct. 1186 (1998); Montgomery v. Carr 101 F.3d 1117, 1123, 1129-30 (6th Cir. 1996) (stating that Virginia "appear[ed] to create a new standard of review for gender based classifications, requiring an 'excecdingly persuasive justification' on the part of the governmental actor," but applying rational basis to the question before the court); Cohen v. Brown Univ., 101 F.3d 155, 183 n.22 (1st Cir. 1996), cert. denied, 117 S. Ct. 1469 (1997); Nabozny v. Podlesny, 92 F.3d 446, 456 n. 6 (7th Cir. 1996) (noting that Virginia used the exceedingly persuasive justification standard instead of the traditional intermediate scrutiny language, but refusing to exprcss an opinion on whether that ruling heightens the level for gender classifications because the issue was not dispositive in the instant case).

101. See, e.g., Engineering Contractors, 122 F.3d at 908 ("[W]e are not at liberty to disregard binding case law that is so closely on point and has only been weakened, rather than directly overruled, by the Supreme Court.") (quoting Florida League of Prof'l Lobbyists v. Meggs, 87 F.3d 457, 462 (11th Cir. 1996)).

102. 458 U.S. 718 (1982).

103. 511 U.S. 127 (1994). 
Protection doctrine and should be recognized as the proper basis of analysis for all types of gender classifications. ${ }^{104}$

\section{A. Providing a Foundation:}

Mississippi University for Women v. Hogan

Mississippi University for Women $v$. Hogan, ${ }^{105}$ which struck down a state statute excluding males from enrolling in the School of Nursing at the all-female Mississippi University for Women (MUW), represents the beginning of the progression towards a more demanding level of scrutiny for gender-based classifications. Justice O'Connor's majority opinion began by noting that the fact that the policy discriminated against males rather than females did not save the statute..$^{106}$ It then set forth the standard of review for gender classifications: "Our decisions also establish that the party seeking to uphold a statute that classifies individuals on the basis of gender must carry the burden of showing an 'exceedingly persuasive justification' for the classification."107 The Court explained that such a burden could only be met by "showing at least that the classification serves 'important governmental objectives and that the discriminatory means employed' are 'substantially related to the achievement of those objectives."'108

Thus, while still appearing to apply intermediate scrutiny, Hogan began the Court's progression towards a more demanding level of scrutiny by adding the concept of an "exceedingly persuasive justification" to the traditional intermediate scrutiny analysis advanced in Craig $v$. Boren ${ }^{109}$ Indeed, Hogan not only added this phrase to the formulation, it made the phrase the centerpiece of the standard of review for genderbased classifications. Hogan thus relegated the traditional intermediate scrutiny language to a mere explanation of how to meet the burden of showing an "exceedingly persuasive justification." did not cite the Court's groundbreaking decision in Craig for either proposition. Instead, the Court cited Wengler v. Druggists Mutual

104. Indeed, in holding that intermediate scrutiny was still the applicable standard for genderbased classifications, the court in Engineering Contractors relied extensively on the fact that Virginia had endorsed Hogan. See Engineering Contractors, 122 F.3d at 907 . When Virginia is viewed in the context of a progression which began with Hogan, such an endorsement makes perfect sense.

105. 458 U.S. 718 (1982).

106. See id. at 723-24 (citations omitted).

107. Id. at 724 (quoting Kirchberg v. Feenstra, 450 U.S. 455, 461 (1981); Personnel Adm'r of Mass. v. Feeney, 442 U.S. 256, 273 (1979)).

108. Id. (quoting Wengler v. Druggists Mutual Ins. Co., 446 U.S. 142, 150 (1980)).

109. See supra note 22 and accompanying text.

110. See Hogan, 458 U.S. at 724. At the very least, this formulation seems to have added another step to the traditional two-step analysis. See Kevin A. Ashley, Casenote, When Worlds Collide: Preemptory Challenges, Gender, and Intermediate Scrutiny in J.E.B. v. Alabama, 46 FLA. L. REv. 261, 282 n.210 (1994). 
Insurance Co. ${ }^{111}$ for the traditional intermediate scrutiny language. By grounding the new test in different case law, the decision further eroded the perception that Craig was the seminal gender-based classification case. Thus, Hogan provided room for a stricter standard of scrutiny without explicitly overruling previous gender discrimination cases. It also increased the likelihood that courts would cite Hogan for the reformulated standard in future gender classification cases. This movement towards a stricter standard was reinforced by another feature of the opinion: a footnote explicitly reserving the question of whether classifications based on gender are inherently suspect. ${ }^{112}$

Hogan also contained specific language, beyond the "exceedingly persuasive justification" catch phrase, that provided a foundation for raising the level of scrutiny beyond the traditional intermediate standard. When the traditional standard is placed within the context of Hogan's language, it appears to be much more difficult for the state to justify gender classifications. For example, the paragraph immediately following the description of the reformulated standard notes that this standard "must be applied free of fixed notions concerning the roles and abilities of males and females."113

Hogan also added language to the analysis in the two prongs of the traditional test. First, courts must ascertain whether the statutory objective "reflects archaic and stereotypic notions." 114 Thus, the state must not "exclude or 'protect' members of one gender because they are presumed to suffer from an inherent handicap or to be innately inferior."115 Turning to the relationship between the means and the state's legitimate and important objective, the Court observed that "[ $t]$ he purpose of requiring a close relationship is to assure that the validity of a classification is determined through reasoned analysis rather than through the mechanical application of traditional, often inaccurate, assumptions about the proper roles of men and women."116

While similar language had been sprinkled throughout other gender classification opinions, O'Connor's opinion "expertly drags the State's justifications through the briar patch of prohibitions to gender based classifications (e.g., 'archaic and stereotypic notions') collected by the Court over the previous decade." 117 Therefore, future cases could use O'Connor's language word for word, citing Hogan to make the standard far more rigorous.

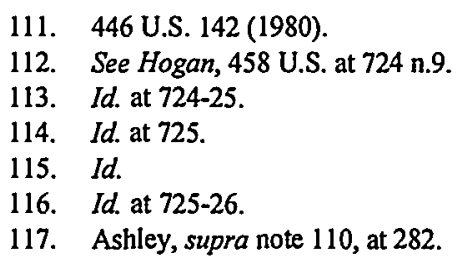


Applying this revised conception of intermediate scrutiny, the Court held MUW's policy invalid. First, the Court was not persuaded by the state's remedial justification that the policy was designed to compensate for discrimination against women. ${ }^{118}$ Indeed, the Court found that women earned an extremely high percentage of nursing degrees, ${ }^{119}$ and that rather than compensating for discrimination against women, the policy tended to "perpetuate the stereotyped view of nursing as an exclusively woman's job." "120

The Court also held that the state did not prove that the classification was substantially and directly related to its objective. Supporting this conclusion, the Court noted that MUW's asserted purpose failed because it allowed men to audit classes in the School of Nursing, and to participate fully in those classes. ${ }^{121}$ Moreover, the Court found that admitting men to nursing classes did not affect teaching style or the performance of female nursing students, and that men did not dominate the classroom discussion in co-educational nursing classes. ${ }^{122}$

Finally, in holding that MUW's policy violated the Equal Protection Clause, O'Connor's opinion reiterated the "exceedingly persuasive" formulation, eschewing any explicit reference to the traditional intermediate scrutiny standard:

Considering both the asserted interest and the relationship between the interest and the methods used by the State, we conclude that the State has fallen far short of establishing the "exceedingly persuasive justification" needed to sustain the gender-based classification. Accordingly, we hold that MUW's policy ... violates the Equal Protection Clause of the Fourteenth Amendment. ${ }^{123}$

B. Continuing the Progression: J.E.B. v. Alabama ex rel. T.B.

After Hogan, twelve years passed before the Court faced another Equal Protection challenge to a gender classification scheme. In 1994, the Court in J.E.B. v. Alabama ex rel. T.B. ${ }^{124}$ held that intentional gender discrimination through the use of peremptory challenges in jury selection was unconstitutional. ${ }^{125}$ Because the previous cases regarding peremptory strikes concerned racial discrimination subject to strict

118. See Hogan, 458 U.S. at 727-30.

119. In 1970, the year before the MUW School of Nursing's first class enrolled, women earned 94 percent of nursing baccalaureate degrees conferred in Mississippi, and 98.6 percent of the degrees earned nationwide. See id. at 729.

120. Id.

121. See id. at 721 n.4, 731 .

122. See id. at 731.

123. Id.

124. 511 U.S. 127 (1994).

125. See id. at 129, 131, 146. 
scrutiny, ${ }^{126}$ J.E.B. served as the perfect vehicle to heighten the standard of scrutiny for gender classifications. It would have been easy for the Court to employ the logic of the racial classification cases, if not explicitly apply strict scrutiny, to peremptory challenges based on gender. Indeed, Justice Blackmun made several references to the similarity between race and gender classifications throughout his majority opinion. ${ }^{127}$ Like the language in Hogan, much of this language could well serve as the basis for the application of strict scrutiny to gender-based classifications. The second paragraph of the opinion provides an example of such language:
Although premised on equal protection principles that apply equally to gender discrimination, all our recent cases... in- volved alleged racial discrimination.... Today we are faced with the question whether the Equal Protection Clause forbids inten- tional discrimination on the basis of gender, just as it prohibits discrimination on the basis of race. We hold that gender, like race, is an unconstitutional proxy .... ${ }^{128}$

While the Court did note that there were some differences between race and gender discrimination, ${ }^{129}$ its holding contained another reference to the similarities. "As with race, the "core guarantee of equal protection, ensuring citizens that their State will not discriminate... would be meaningless were we to approve the exclusion of jurors on the basis of such assumptions, which arise solely from the jurors' [gender]."'130 Thus, by drawing parallels between gender and racial classifications, the $J . E . B$. opinion provided a firm basis for raising the standard of scrutiny to be applied to gender-based classifications in the future.

In addition to equating race and gender discrimination, J.E.B. also provided a vehicle for elevating the standard of scrutiny for genderbased classifications through its recitation of the "exceedingly persuasive justification" standard: "Under our equal protection jurisprudence,

126. See Georgia v. McCollum, 505 U.S. 42 (1992); Edmonson v. Leesville Concrete Co., 500 U.S. 614 (1991); Powers v. Ohio, 499 U.S. 400 (1991); Batson v. Kentucky, 476 U.S. 79 (1986).

127. See infra notes 128, 130 and accompanying text; see also J.E.B., 511 U.S. at 136 ("Certainly, with respect to jury service, African-Americans and women share a history of total exclusion...."); id. at 140 ("Discrimination in jury selection, whether based on race or gender, causes harm to the litigants, the community, and the individual jurors who are wrongfully exeluded from participation in the judicial process."); id. at 145 ("Failing to provide jurors the same protection against gender discrimination as race discrimination could frustrate the purpose of Batson itself."). Indeed, one commentator noted that the opinion "assumes a level of similarity between race and gender beyond any the Court has ever announced." Ashley, supra note 110, at 285.

128. J.E.B., 511 U.S. at 128-29.

129. See id. at 135 ("While prejudicial attitudes toward women in this country have not been identical to those held toward racial minorities, the similarities between the experiences of racial minorities and women, in some contexts, 'overpower these differences."' (citation omitted)).

130. Id. at 146 (quoting Batson v. Kentucky, 476 U.S. 79, $97-98$ (1986)) (substituting the word "gender" for "race" as the final word in that quotation) (alterations in original). 
gender-based classifications require an 'exceedingly persuasive justification' in order to survive constitutional scrutiny."131 Following this pronouncement, the Court stated that the only question was whether the discrimination substantially furthers an important state interest. ${ }^{132}$ The opinion followed this characterization of the standard with the same footnote found in Hogan, reinforcing the proposition that the issue of whether classifications based on gender were inherently suspect remained an open question. ${ }^{133}$ While the reference to traditional intermediate scrutiny language indicated the survival of this standard in one respect, the fact that the Court provided no citation for the traditional language ensured its relegation to a mere description of how to show an exceedingly persuasive justification, and provided the Court in its next opinion considering gender-based classifications with the opportunity to drop the language entirely. ${ }^{134}$

\section{United States v. Virginia and \\ the "Exceedingly Persuasive Justification" Standard}

Two years after the J.E.B. decision, the Supreme Court provided the latest step in the progression toward a higher level of scrutiny for gender-based classifications. Its decision in United States v. Virginia ${ }^{135}$ concerned the highly publicized challenge to VMI's exclusively male admissions policy. The majority opinion, which was written by Justice Ginsburg and joined by five other members of the Court, ${ }^{136}$ held that VMI's male-only admissions policy violated the Equal Protection Clause and that the proposed remedy was insufficient to cure the constitutional violation. ${ }^{137}$

Justice Ginsburg's opinion began its analysis by noting that "the core instruction of this Court's pathmarking decisions in [J.E.B. and Hogan]" was that "[p]arties who seek to defend gender-based government action must demonstrate an 'exceedingly persuasive justification' for that action." ${ }^{\prime 38}$ However, while most references to the J.E.B./Hogan

131. Id. at 136 (citations omitted).

132. See id. at 136-37.

133. See id. at 137 n.6.

134. In fact, Justice O'Connor's concurrence specifically mentions the "exceedingly persuasive" requirement without referring to any of the language associated with the traditional intermediate scrutiny standard. See id. at 146-47 (O'Connor, J., concurring).

135. 116 S. Ct. 2264 (I996).

I36. Chief Justice Rehnquist wrote a concurring opinion, see id. at 2287-91, Justice Scalia dissented, see id. at 2291-2309, and Justice Thomas did not take part in the consideration or decision of the case, see id. at 2287.

137. See id. at 2276. The discussion of the case will focus on the violation of the Equal Protection Clause. The analysis of the remedial plan, which consisted of a separate program for women located at an all-female eollege, does not significantly contribute to the consideration of the standard applied to gender-based classifications.

I38. Id. at 2274 . 
standard include the "substantial relation to important governmental objectives" formulation, the only description following this pronouncement in Virginia was that the standard involved "skeptical" scrutiny which "responds to volumes of history."139

The opinion then described the development of the standard, summarizing the Court's current directions with one long paragraph. ${ }^{140}$ First, Justice Ginsburg noted that the Court had not equated gender classifications "for all purposes" to those based on race or national origin. ${ }^{141}$ This observation was followed by a footnote stating that "[t]he Court has thus far reserved most stringent judicial scrutiny for classifications based on race or national origin, but last Term observed that strict scrutiny of such classifications is not inevitably 'fatal in fact."'142 Next, the Court set forth the standard:

To summarize the Court's current directions for [gender classifications]:... the reviewing court must determine whether the proffered justification is "exceedingly persuasive." The burden of justification is demanding and it rests entirely on the State. The State must show "at least that the [challenged] classification serves 'important governmental objectives and that the discriminatory means employed' are 'substantially related to the achievement of those objectives."

The opinion also noted that the justification must be "genuine," and "must not rely on overbroad generalizations about the different talents, capacities, or preferences of males and females." 144

The Court then stated that the "heightened review standard does not make sex a proscribed classification," because while "inherent differences are no longer accepted as a ground for race or national origin classifications," in contrast, "[p]hysical differences between men and women ... are enduring."145 The opinion continued by describing the types of gender-based classifications which are permissible: "Sex classifications may be used to compensate women 'for particular economic disabilities [they have] suffered,' to 'promot[e] equal employment opportunity,' [and] to advance full development of the talent and capacities of our Nation's people."146 Such classifications, however, may not be used "for denigration of members of either sex or for artificial constraints on an individual's opportunity."147 The Court concluded its

139. Id.

140. See id. at 2275 .

141. Id.

142. Id. at 2275 n. 6 (citing Adarand Constructors, lnc. v. Peña, 515 U.S. 200 (1995)).

143. Id. at 2275 (citations omitted) (alteration of internal quotation in original).

144. Id.

145. Id. at 2276 (citations omitted).

146. Id. (citations omitted) (alterations of internal quotation in original).

147. Id. 
discussion of the relevant standard by stating that when the record was compared to that standard, "Virginia has shown no "exceedingly persuasive justification' for excluding all women from ... VMI.,"148

Applying the "exceedingly persuasive justification" standard to VMI, the Court considered the justifications advanced by Virginia in defense of VMI's all-male admissions policy. First, Virginia asserted that single-sex education provides important educational benefits, and that providing a male-only option contributes to the diversity of education offered by the state. ${ }^{149}$ While Justice Ginsburg acknowledged that singlesex education does benefit at least some students, and that diversity among public educational institutions can serve the public good, she ultimately rejected the justification because Virginia did not show that VMI was established, or had been maintained, to diversify educational opportunities through its exclusion of women. ${ }^{150}$

The Court then addressed Virginia's second justification for VMI's admissions policy, that "VMI's adversative method of training provides educational benefits that cannot be made available, unmodified, to women." 151 The Court rejected this argument as well, writing that " $[t]$ he notion that admission of women would downgrade VMI's stature, destroy the adversative system, and, with it, even the school, is a judgment hardly proved, a prediction hardly different from other selffulfilling prophec[ies] once routinely used to deny rights or opportunities." 152 Thus, "[t]he State's justification for excluding all women from 'citizen soldier' training for which some are qualified, in any event, cannot rank as 'exceedingly persuasive' as we have explained and applied that standard."153 The Court concluded its discussion by noting that VMI's goal of producing "citizen-soldiers" was surely great enough to accommodate women, ${ }^{154}$ and writing that "in sum, [Virginia] 'has fallen far short of establishing the "exceedingly persuasive justification" that must be the solid base for any gender defined classification." 155

148. Id.

149. See id. (citing Brief for Cross-Petitioners at 20, 25).

150. See id. at 2277. In concluding that the diversity justification was a rationalization, rather than a description of the actual purpose of the classification, the Court noted both that educational opportunities for women were scarcely considered when VMl was established and that the State did not provide opportunities for single-sex education to women. See id. at 2277-79.

151. Id. at 2279.

152. Id at $\mathbf{2 2 8 0}$ (footnotes and citation omitted). Examples of this include denial of admission to the bar and access to legal education, medical facilities, policing, and federal military academies. See id. at $2280-81$.

153. Id. at 2281.

154. See id. at 2281-82.

155. Id. at 2282 . 
D. Identifying the Standard of Review for Gender-Based Classifications: The "Exceedingly Persuasive Justification" Standard Is More Demanding than Intermediate Scrutiny

\section{Intermediate Scrutiny: A Temporary Measure?}

Even before the decision in Virginia, there were indications that some members of the Court viewed the traditional intermediate scrutiny standard as a temporary measure. For example, footnotes inserted into three gender classification opinions assert that the issue of whether classifications based on gender were inherently suspect is an open question. As noted above, Hogan and J.E.B. both contained such footnotes. ${ }^{156}$ In addition, Justice Ginsburg included a similar footnote in her concurrence in Harris v. Forklift Systems, Inc. ${ }^{157}$ Apparently, if the Court were to decide that classifications based on gender are inherently suspect, the classifications would be subject to strict scrutiny. ${ }^{158}$ Indeed, one commentator has noted that by inserting the open question footnote in her Harris concurrence, Justice Ginsburg "all but invited litigants to bring [the strict scrutiny argument] up again."159 Moreover, while footnotes do not decide cases, they often contain clues about the future leanings of the Court, ${ }^{160}$ and this may well be the case here.

Regardless, the four most recent additions to the Court appear to be fairly open to a higher standard of scrutiny for gender classifications. Justice Ginsburg is the most obvious supporter ${ }^{161}$ but during their confirmation hearings the other three conveyed some skepticism about traditional intermediate scrutiny. For example, Justice Souter stated during his confirmation hearings that "[the intermediate scrutiny test] is not good, sound protection. It is too loose." ${ }^{.162}$ Similarly, Justices Breyer and

156. See supra notes 112,133 and accompanying text.

157. 510 U.S. 17, 26 n.* (1993) (Ginsburg, J., concurring). Significantly, the footnote characterized the Court's equal protection jurisprudence as requiring an "exceedingly persuasive justification" for gender-based classifications, without referring to intermediate scrutiny or the language traditionally associated with that standard.

158. See J.E.B. v. Alabama ex rel. T.B., 511 U.S. 127, 154 (1994) (Rehnquist, C.J., dissenting) ("Classifications based on race are inherently suspect, triggering 'strict scrutiny' ...."); Michael M. v. Superior Court, 450 U.S. 464, 468 (1981) (plurality opinion) ("[W]e have not held that genderbased classifications are 'inherently suspect' and thus we do not apply so-called 'strict scrutiny'....").

159. Lyle Denniston, The Center Moves, the Center Remains, 40 N.Y.L. SCH. L. REv. 877, 883 (1996). Another commentator observes that Justice Ginsburg has always viewed intermediate scrutiny as a mere compromise. See Collin O'Connor Udell, Note, Signaling a New Direction in Gender Classification Scrutiny: United States v. Virginia, 29 CoNN. L. REv. 521, 549-50 (1996).

160. See John E. NowaK \& Ronald D. Rotunda, Constitutional Law 396 (5th ed. 1995) (examining footnote four in United States v. Carolene Products, 304 U.S. 144, 152-53 n.4 (1938)).

161. In addition to writing the footnote in her Harris concurrence, as an attorney for the ACLU Justice Ginsburg worked throughout the 1970 s to strengthen the standard of review for gender-based classifications. See generally Deborah L. Markowitz, In Pursuit of Equality: One Woman's Work to Change the Law, 14 Women's RTS. L. REP. 335 (1992); Udell, supra note 159.

162. Ruth Marcus \& Michael Isikoff, Souter Declines Comment on Abortion, Wash. Post, Sept. 
Thomas indicated a willingness to apply a more demanding standard to gender-based classifications during their confirmation hearings. ${ }^{163}$ Therefore, the open question footnotes combined with the perspectives of the recent additions to the Court indicate that strict scrutiny is still a possibility for gender classifications.

2. Virginia's Indications of a Higher Standard of Scrutiny for GenderBased Classifications

a. Placement and Frequency of the "Exceedingly Persuasive Justification" Formulation in Virginia

As Chief Justice Rehnquist ${ }^{164}$ and Justice Scalia ${ }^{165}$ recognized in their respective concurring and dissenting opinions, the Virginia majority opinion used the phrase "exceedingly persuasive" nine times ${ }^{166}$ while describing that standard only twice as requiring that "the classification serves an important governmental objective and that the discriminatory means employed are substantially related to the achievement of those objectives." 167 This fact alone may support the conclusion that the Court is moving away from traditional intermediate scrutiny for gender classifications.

Beyond the number of references, the placement of the references to the "exceedingly persuasive justification" is important as well. For example, the first paragraph of the analysis in the opinion notes that "the core instruction" of the Court's "pathmarking decisions" in J.E.B. and Hogan is that the parties defending gender-based classifications must demonstrate an "exceedingly persuasive justification." ${ }^{\prime 68}$ Because it is the initial comment in the analysis, the standard could easily be construed as the basic foundation for evaluating the classification. The assertion that the formulation is a "core instruction" of "pathmarking decisions" reinforces this impression. In addition, the fact that the traditional intermediate scrutiny language is not included in the announcement of such an important principle appears to relegate

\section{4,1990 , at A1.}

163. See Nomination Hearings: Justice Breyer Gets Warm Reception From Senate Judiciary, 52 CONG. Q. WEEkLY RPT. 1958, 1964 (1994) (responding to Senator DeConcini's observation that the Court seems to be moving closer to applying strict scrutiny to gender discrimination; and responding to the question whether he is "stuck on the intermediate [scrutiny standard] by any means," Justice Breyer stated, "No, I'm certainly not ...."); Dennis DeConcini, Examining the Judicial Nomination Process: The Politics of Advice and Consent, 34 ARIZ. L. REv. I, 16 n.47 (1992) (noting that "[m]ore so than even Justice Souter, Thomas supported heightened scrutiny review for gender discrimination cases.").

164. See United States v. Virginia, 116 S. Ct. 2264, 2288 (1996) (Rehnquist, C.J., concurring).

165. See id. at 2294 (Scalia, J., dissenting).

166. See id. at 2271, 2274 (three times), 2275, 2276, 2281, 2282, 2287.

167. Id. at 2271,2275 .

168. Id. at 2274. 
the traditional standard to the background of the analysis-if not rendering it completely irrelevant. In contrast, the "exceedingly persuasive justification" requirement is used to indicate the Court's conclusions on a number of issues. Indeed, Virginia found that the state failed to show an "exceedingly persuasive justification" for either its admissions policy or the remedy at four different places in the opinion. ${ }^{169}$

\section{b. Additional Notable Textual Features of the Virginia Opinion}

In addition to Virginia's repeated use of the "exceedingly persuasive justification" phrase, the opinion contains a number of other features that support the view that the case imposes a new standard for gender classifications. First, the Court never states that it is applying intermediate scrutiny. Its only two characterizations of the standard of scrutiny it is applying are "skeptical scrutiny"170 and "heightened review standard," "171 both of which indicate a more demanding level of analysis than intermediate scrutiny.

Footnote six of the opinion provides additional support for the view that the Virginia Court intended to continue the progression towards raising the level of scrutiny applied to gender classifications. The footnote reads, "The Court has thus far reserved most stringent judicial scrutiny for classifications based on race or national origin, but last Term observed that strict scrutiny of such classifications is not inevitably "fatal in fact."'172 While this appears to indicate that strict scrutiny is not being applied to the case at bar, footnote six may foreshadow the imminent application of strict scrutiny to future gender classifications. One can infer this from the phrase "thus far," which suggests that the status quo is about to change, as well as from the word "but," which is typically followed by a proposition which is contrary to the one preceding it. In this context, the Court's assertion that strict scrutiny is not inevitably fatal in fact supports the view that it is possible to apply strict scrutiny to gender-based classifications, even though these gender classifications may be justified by the inherent differences that are no longer accepted as a ground for race or national origin classifications that are already subject to strict scrutiny.

Finally, labeling Hogan and J.E.B., decisions which most strongly indicate a higher level of scrutiny for gender classifications, as "pathmarking decisions," the Court is changing the level of scrutiny. Similarly, while Craig $v$.

169. See id. at $2276,2281,2282,2286-87$.

170. Id. at 2274.

171. Id. at 2276.

172. Id. at 2275 n.6 (citing Adarand Constructors, Inc. v. Pcrna, 115 S. Ct. 2097, 2117 (1995)).

173. Id. at 2274 . 
Boren $^{174}$ would seem to merit mention as a pathmarking decision-since it was the first case to articulate the intermediate scrutiny standard-the case is not cited anywhere in the opinion. One can at least infer that if the Court was adhering to the traditional formulation for intermediate scrutiny, it would take care to mention Craig in an opinion involving gender classifications. Thus, Craig's absence provides further evidence that the Court is moving away from traditional intermediate scrutiny.

\section{Virginia as the Third Step in the Progression to a Higher Level of Scrutiny}

The preceding discussion has demonstrated that Hogan, J.E.B., and Virginia have created a more demanding standard for gender-based classifications; traditional intermediate scrutiny is no longer the proper standard of analysis. However, it is also important to recognize that, contrary to Justice Scalia's suggestion, ${ }^{175}$ Justice Ginsburg's opinion in Virginia declined to step through the door opened by J.E.B. and did not apply strict scrutiny to gender classifications. After Hogan and J.E.B., the next logical step in the progression would either have been to apply strict scrutiny explicitly by equating race and gender discrimination, or to define the standard as "exceedingly persuasive" while dropping the traditional intermediate scrutiny language entirely. Virginia did not employ either option.

The first option would have been nearly impossible to accomplish in the Virginia case, because it would have been very difficult to bring race into the context of VMI. While the school was initially reluctant to admit African-Americans, ${ }^{176}$ about $7 \%$ of VMI's students are AfricanAmerican, and it has race-based recruitment and retention programs in place. ${ }^{177}$ Thus, while much of the language in J.E.B. could be attributed to the context of the decision, such an approach would have been a major stretch in Virginia.

Moreover, the mechanics of the presentation of the case in Virginia made it difficult, in a more practical sense, to apply strict scrutiny. A potentially significant feature of the government's brief in Virginia was that it asserted that strict scrutiny was the correct constitutional standard for evaluating classifications based on gender. ${ }^{178}$ However, at oral argument the government appeared to back away from its

174. 429 U.S. 190 (1976).

175. See Virginia, 116 S. Ct. at 2294 (Scalia, J., dissenting).

176. VMI did not admit African-American students until 1968. See id. at 2282 n.16.

177. See United States v. Virginia, 766 F. Supp. 1407, 1436-37 (W.D. Va. 1991).

178. See Brief for the Petitioner at 33-36 United States v. Virginia, No. 94-1941 (S. Ct. brief filed Nov. 16, 1995). The government's argument, however, was not wholly based on the application of strict scrutiny. Indeed, much of the argument was focused on the "exceedingly persuasive justification" standard. See id. at 20-33, 37-48. 
argument for strict scrutiny. It explained that because the Court had inserted the open question footnote in several gender classification cases, the government "thought the question might come up of asking [them] what [they] thought the right standard [was]."179 Thus, despite the openings provided by questions from Justice O'Connor, the government provided her and Justice Ginsburg no cover if they were anticipating an assault from the conservative side of the Court on that issue during the coming bargaining. ${ }^{180}$

As a result, language in Virginia appears to foreclose the application of strict scrntiny (at least for now) to any gender classification: "[T] he heightened review standard our precedent establishes does not make sex a proscribed classification." 181 This passage is important because the category of proscribed classifications appears to be limited to race and national origin, ${ }^{182}$ which are the only classifications to be analyzed under strict scrutiny. ${ }^{183}$ Because sex is not a proscribed classification, strict scrutiny therefore cannot be used to analyze any scheme which uses gender as the basis for different treatment.

However, the Court again left open the possibility that strict scrutiny could apply to a future case: "Without equating gender classifications, for all purposes, to classifications based on race or national origin, the Court ... has carefully inspected official action that closes a door or denies opportunity to women (or to men)."184 The observation in the following footnote that strict scrutiny is not inevitably fatal in fact ${ }^{185}$ may also be important in persuading the justices to apply this level of scrutiny in the future.

Furthermore, if the pursuit of strict scrutiny is seen as the gradual result of a logical, case-by-case progression, ${ }^{186}$ any move to strict scrutiny in Virginia could have been seen as too radical. One could easily foresee a situation similar to that which took place after Frontiero $v$. Richardson, ${ }^{187}$ in which the plurality applied strict scrutiny too soon, before a sufficient doctrinal foundation had been laid, and dealt a fatal blow to the strategy pursued by Ginsburg in the 1970 s. ${ }^{188}$ Indeed, the

179. Transcript of oral argument at 12, United States v. Virginia, Nos. 94-1941, 94-2107, 1996 WL 16020 (U.S.Oral.Arg. Jan. 17, 1996).

180. See Denniston, supra note 159 , at 885 .

181. United States v. Virginia, 116 S. Ct. 2264, 2276 (1996).

182. See id.

183. See id. at 2275 n.6; see also Clark v. Jeter, 486 U.S. 456, 461 (1988).

184. Virginia, $116 \mathrm{~S}$. Ct. at 2275 (emphasis added).

185. See id. at 2275 n.6.

186. As an attorney for the ACLU in the early 1970 s Justice Ginsburg used a somewhat similar approach in pursuing strict scrutiny for gender-based classifications-bringing a series of "clcar winner[s]" before the Court to lay the groundwork for the application of strict scrntiny. See Udell, supra note 159 , at $525-27$.

187. 411 U.S. 677 (1973) (plurality opinion).

188. Ginsburg's strategy led to the adoption of strict scrutiny by a plurality of the Court in 
Frontiero decision arguably set the fight for strict scrutiny back twenty years, forcing the crusaders for strict scrutiny to pursue incremental victories, which began with the Court's adoption of traditional intermediate scrutiny. ${ }^{189}$ Justice Ginsburg may have been determined not to let the Court make the same mistake twice, and therefore did not want to risk what could have been another tentative plurality in support of strict scrutiny.

While Justice Ginsburg's hesitance to employ strict scrutiny in Virginia is understandable, she was probably too cautious concerning the traditional intermediate scrutiny language. J.E.B. framed the traditional language as a fairly innocuous reference, without a citation. Therefore, Virginia probably could have succeeded in dropping this language altogether and just used the "exceedingly persuasive justification" phrase. Justice Ginsburg had a clear winner on her hands in Virginia, as evidenced by the six person majority and Chief Justice Rehnquist's concurrence in the judgment. It is therefore possible to view the opinion as a missed opportunity. While Virginia's version of the "exceedingly persuasive justification" formulation clearly requires a more stringent level of analysis for gender-based classifications than the traditional intermediate scrutiny, the limited use of the traditional intermediate scrutiny language and the distinction between race and national origin discrimination and gender discrimination make it equally clear that Virginia's new standard falls short of strict scrutiny.

\section{Summary of the Hogan-J.E.B.-Virginia Progression}

In the last fifteen years, the Supreme Court, through the HoganJ.E.B.-Virginia progression, has eviscerated the traditional intermediate scrutiny standard for gender-based classifications. However, this does not mean that strict scrutiny is the appropriate level of analysis. Instead, the Court has dictated that the "exceedingly persuasive justification" standard, which is certainly more demanding than intermediate scrutiny but does not reach the level of strict scrutiny, applies to gender-based classifications. This standard is consistent with the Court's gender-based equal protection jurisprudence, including the "pathmarking decisions" in Hogan and J.E.B., and should be recognized as the operative mode of analysis for gender-based classifications.

Frontiero. However, Ginsburg believed that the plurality had moved too quickly, with Reed v. Reed, 404 U.S. 71 (1971), as the only building block supporting Frontiero. See Udell, supra note 159, at 52527. She proved to be correct; Frontiero is still the only Supreme Court opinion to apply strict scrutiny to gender classifications.

189. After Frontiero, Ginsburg ceased arguing for the application of strict scrutiny to gender classifications, and her ACLU amicus brief in Craig v. Boren, 429 U.S. 190 (1976), was pivotal in the Court's crafting of intermediate scrutiny. See Udell, supra note 159, at 527-28. 


\section{III}

The "Exceedingly Persuasive Justification" Standard Applies TO All GENDER-BASEd Classifications

While this Comment concludes that the Hogan-J.E.B.-Virginia progression raised the level of scrutiny for gender-based classifications, its effect on gender-based affirmative action remains to be addressed. As discussed in Part I.C., the circuit courts are split on which standard of analysis to apply to affirmative action programs. The Sixth Circuit subjects all affirmative action programs to strict scrutiny, regardless of the classification involved. ${ }^{190}$ This means that gender-based affirmative action programs are subjected to a higher level of scrutiny than other gender-based classifications. In contrast, several other circuit courts subject affirmative action programs to the same level of scrutiny as the classification involved. ${ }^{191}$

This split among the circuits should be resolved by applying the same "exceedingly persuasive justification" standard to all gender-based classifications, including affirmative action. Virginia provides support for this conclusion. Moreover, subjecting gender classifications to the more demanding "exceedingly persuasive justification" standard reaches an appealing result in terms of the paradoxes associated with genderbased affirmative action under strict and intermediate scrutiny.

\section{A. Gender-Based Affirmative Action Should Be Subject to the Same Level of Scrutiny as Other Gender-Based Classifications}

Applying the same level of "exceedingly persuasive justification" scrutiny to all gender-based classifications, including affirmative action, correctly resolves the circuit split. Both affirmative action and genderbased classification case law support the conclusion that gender and race-based affirmative action programs should be treated differently, while gender classifications, whether they involve affirmative action or not, should be treated the same.

While the Court's most important affirmative action decisions in the last few years, Croson and Adarand, apply strict scrutiny, they focus entirely on race and do not mention the issue of gender-based affirmative action. Thus, it is unlikely that these decisions mandate the application of strict scrutiny to gender-based programs. The only Supreme Court guidance on the issue supports this conclusion. Soon after Croson was announced, the Court affirmed a Sixth Circuit decision which employed intermediate scrutiny in its analysis of a set-aside program for women-owned businesses (WBEs). ${ }^{192}$

190. See supra note 38.

191. See supra notes 40-43.

192. See Michigan Rd. Builders Ass'n v. Miliken, 834 F.2d 583 (6th Cir. 1987), aff'd, 
The application of the same level of scrutiny to all gender-based classifications also finds support in a number of Supreme Court genderbased classification cases, which analyze so-called benign discrimination against men under the same intermediate scrutiny standard used to scrutinize other types of gender-based classifications. ${ }^{193}$ Indeed, two of the most important gender classification cases in the last twenty years, Craig v. Boren ${ }^{194}$ and Mississippi University for Women v. Hogan ${ }^{195}$ fall under this description. In contrast, Frontiero, the only case that used strict scrutiny to analyze any kind of gender classification, took place over twenty-five years ago, and that proposition has never commanded a majority of the Supreme Court. The benign discrimination cases, which involve classifications favoring women, are certainly much more analogous to gender-based affirmative action than Croson and Adarand, which do not even mention gender in their analysis.

In addition, there is a strong argument that the anomalies associated with subjecting gender-based affirmative action to a lower level of scrutiny than race-based affirmative action ${ }^{196}$ are acceptable under the Court's current interpretation of the Equal Protection Clause. The level of analysis for gender-based classifications is less demanding than that for racial classifications because race-based classifications are more dangerous, and less likely to serve a beneficial purpose. ${ }^{197}$ The distinction between gender and racial classifications is that inherent differences exist between men and women, which may legitimately warrant different treatment under the law. ${ }^{198}$ In contrast, such inherent differences are no longer accepted as a ground for racial classifications, therefore, disparate treatment based on race is rarely justified. ${ }^{199}$

489 U.S. 1061 (1989).

193. See, e.g., Caban v. Mohammed, 441 U.S. 380 (1979) (striking down statute which permits unwed mother, but not unwed father, to block the adoption of their child simply by withholding consent); Orr v. Orr, 440 U.S. 268 (1979) (invalidating statutory scheme which provided that husbands, not wives, may be required to pay alimony); Califano v. Webster, 430 U.S. 313 (1977) (upholding Social Security Act provision allowing women to exclude from the computation of her "average monthly wage" three more lower earning years than a similarly situated man).

194. 429 U.S. 190 (1976). Craig involved a statute which prohibited the sale of $3.2 \%$ beer to males under the age of 21 and to females under the age of 18 . The Court, providing the basis for the intermediate scrutiny standard, held that the statute was invalid because it invidionsly discriminated against males 18-20 years of age. See id. at 197, 204.

195. 458 U.S. 718 (1982). As discussed supra, Part ll.A., Hogan began the progression toward a higher level of scrutiny for gender classifications, but the standard it applied was still considered to be intermediate scrutiny.

196. See supra notes $45-46$.

197. See Peter Lurie, Comment, The Lav as They Found It: Disentangling Gender-Based Affirmative Action Programs From Croson, 59 U. CHI. L. REv. 1563, 1580 (1992).

198. See Virginia, 116 S. Ct. at 2276; Lurie, supra note 197, at 1580.

199. See Virginia, 116 S. Ct. at 2276; City of Richmond v. J.A. Croson Co., 488 U.S. 469, 505 (1989). 
Furthermore, the Supreme Court has consistently stated that the level of analysis under equal protection should not change based on the group that is disadvantaged by the classification at issue. Men receive the same level of protection as women, ${ }^{200}$ and whites receive the same level of protection as minorities. ${ }^{201}$ Instead, the standard changes based on the type of classification at issue. Classifications based on race are subject to strict scrutiny, ${ }^{202}$ and classifications based on gender are subject to the "exceedingly persuasive justification" standard. ${ }^{203}$ Thus, women and men are not compared to different races under the Equal Protection Clause; they are compared to each other. Therefore, the apparent anomaly of making it more difficult to remedy past racial discrimination than gender discrimination is actually consistent with the teachings of the Court's equal protection jurisprudence.

The Virginia opinion contains several features which reinforce the conclusion that the same standard should apply to all gender-based classifications, including affirmative action. For example, the opinion equates all gender classifications in noting that "the Court, in post-Reed decisions, has carefully inspected official action that closes a door or denies opportunity to women (or to men). ${ }^{204}$ Similarly, the Court notes that "[i]nherent differences between men and women ... remain cause for celebration, but not for denigration of the members of either sex or for artificial constraints on an individual's opportunity, ${ }^{, 205}$ and that "'all gender-based classifications today' warrant 'heightened scrutiny. "'2206 Finally, the Sixth Circuit's application of strict scrutiny for gender-based affirmative action programs stands in direct opposition to the Court's foreclosure of strict scrutiny for gender-based classifications, ${ }^{207}$ and therefore cannot be followed. Consequently, gender-based affirmative action, like all other gender-based classifications, should be subject to the "exceedingly persuasive justification" standard.

200. See, e.g., Mississippi Univ. for Women v. Hogan, 458 U.S. 718, 724 n.9 (1982) (“[W]hen a classifieation expressly discriminates on the basis of gender, the analysis and level of serutiny applied to determine the validity of the classification do not vary simply because the objective appears acceptable to individual Members of the Court.").

201. See, e.g., Croson, 488 U.S. at 494 ("The guarantee of equal protection cannot mean one thing when applied to one individual and something else when applied to a person of another color.").

202. See supra note 10.

203. See supra note 143 .

204. United States v. Virginia, 116 S. Ct. 2264, 2275 (1996) (emphasis added).

205. Id. at 2276 (emphasis added).

206. Id. at 2286 (citing J.E.B. v. Alabama ex rel. T.B., 511 U.S. 127, 136 (1994)) (emphasis added).

207. See supra Part ll.D.3. 


\section{B. The "Exceedingly Persuasive Justification" Standard's Effect on the Paradoxes Associated with Gender-Based Affirmative Action}

In terms of the paradoxes associated with gender-based affirmative action, Virginia's "exceedingly persuasive justification" standard is appealing. Of the three paradoxes identified above, ${ }^{208}$ this approach lessens the effect of those associated with intermediate scrutiny, and eliminates the paradox associated with strict scrutiny. The two paradoxes associated with intermediate scrutiny are (1) that white men would have more protection against reverse discrimination through race-based affirmative action programs than women have against gender discrimination, and (2) that race-based affirmative action programs would be more difficult to justify than gender-based plans. Both of these paradoxes are still present under Virginia's "exceedingly persuasive justification" standard, but they are not as pronounced because the level of scrutiny has been raised for gender-based affirmative action. Moreover, as explained above, these two paradoxes are fully consistent with the Court's equal protection jurisprudence. ${ }^{209}$

On the other hand, the paradox associated with the application of strict scrutiny to gender-based affirmative action is eliminated by the application of the new standard. While applying strict scrutiny meant that men received more protection from "reverse discrimination" than women did from the more traditional form of gender discrimination, both men and women now receive the same "exceedingly persuasive justification" level of protection.

Thus, courts should analyze gender-based affirmative action plans under the "exceedingly persuasive justification" standard. This conclusion is supported by affirmative action and gender-based classification case law, and also leads to the most effective resolution of the paradoxes associated with gender-based affirmative action. The remaining issue, examined in Part IV below, is determining the specific requirements associated with Virginia's new standard for analyzing the validity of gender-based affirmative action plans.

\section{IV}

Justifying GendeR-Based Affirmative Action Under the "EXCEEDINGLY PERSUASIVE Justification" STANDARD

One problem with determining the effect of the "exceedingly persuasive justification" standard on gender-based affirmative action is that no court has analyzed an affirmative action plan under this new standard. The only court to address this issue after Virginia incorrectly used

208. See supra notes $45-48$ and accompanying text.

209. See supra notes 196-203 and accompanying text. 
traditional intermediate scrutiny in its analysis. ${ }^{210}$ However, based on the lower court approaches described in Part I.D., as well as the Supreme Court's progression toward a higher level of scrutiny, it is possible to discern how a government entity might justify a gender-based affirmative action plan under Virginia's conception of gender and the Equal Protection Clause.

The "exceedingly persuasive justification" standard affects both prongs of the traditional Equal Protection analysis. ${ }^{211}$ The new test affects the government interest prong in two ways. First, it demands a more compelling government interest to support a gender-based affirmative action program. Remedying societal discrimination in the relevant economic sphere remains a permissible government interest justifying gender-based affirmative action programs. Virginia's test, however, defines the scope of the relevant economic sphere more narrowly than did the traditional intermediate scrutiny. Second, the new "exceedingly persuasive justification" standard heightens the government's evidentiary burden to demonstrate the validity of this interest. Virginia mandates that the government present persuasive evidence to support its purpose, a fairly demanding evidentiary burden.

With regard to the second prong of the analysis, Virginia's "exceedingly persuasive justification" standard should make it more difficult to satisfy the required means-end relationship between the affirmative action program and the proffered government interest. In contrast to traditional intermediate scrutiny, the government likely must consider alternative remedies, and the goals of the program likely must be more closely linked to the proportion of qualified women.

210. See Engineering Contractors Ass'n v. Metropolitan Dade County, 122 F.3d 895, 907 (11th Cir. 1997), cert. denied, 118 S. Ct 1186 (1998). Again, the Eleventh Circuit's main objection to the use of the "exceedingly persuasive justification" standard was Virginia's endorsement of Hogan. This objection has been addressed above. See supra note 104; supra Part 11. The court also relied upon Chief Justice Rehnquist's concurring opinion, which suggested that the "exceedingly persuasive justification" phrase is "best confined... as an observation on the difficul-ty of meeting the applicable test, not as a formulation of the test itself." See Engineering Contractors, 122 F.3d at 908 (quoting United States v. Virginia, 116 S. Ct. 2264, 2288 (1996) (Rehnquist, C.J., coneurring)). The court also cited Justice Scalia's dissenting opinion suggesting that the phrase should be confined to serving as shorthand for traditional intermediate scrutiny. See id. (citing Virginia, $116 \mathrm{~S}$. Ct. at 2294 (Scalia, J., dissenting)). The obvious problem with this approach is that it is dangerous to rely on separate opinions when interpreting a majority opinion. Justices write separately precisely because they disagree with the majority opinion. This concept is borne out by the characterizations of the citations to both justices; they both "suggested" that the pbrase be confined to a description of traditional intermediate scrutiny. See id. at 908 . This is hardly compelling precedent, and should not be the basis upon which to decide a question as important as the applicable standard of scrutiny in the equal protection context.

211. Again, this Comment's discussion is limited to the government contracting context. See supra note 9. 


\section{A. Asserting a Permissible Government Interest}

\section{Societal Discrimination in the Relevant Economic Sphere}

Under the government-interest prong, Virginia supports the notion, associated with intermediate scrutiny, ${ }^{212}$ that attempting to remedy societal discrimination is a permissible justification for gender-based affirmative action. The limitation on this justification-that the discrimination had to have occurred in the relevant economic sphere-is also supported by the Virginia opinion and is a feature of the "exceedingly persuasive justification" standard. However, because the economic sphere is more narrowly defined than it was under traditional intermediate scrutiny, Virginia's more demanding "exceedingly persuasive justification" standard will have a limiting effect on the ability of government entities to justify gender-based affirmative action programs.

\section{a. Remedying Societal Discrimination}

Identifying the appropriate level of scrutiny for the analysis of gender-based affirmative action has a significant impact on the type of discrimination required to justify the program under the governmentinterest prong of the inquiry. While it may be extremely difficult to meet the strict scrutiny requirement that a specific governmental entity has participated in past discrimination against a protected class, general societal discrimination is accepted as a justification under intermediate scrutiny and is far easier to prove. ${ }^{213}$ In adopting the latter, more lenient, position, both the Eleventh Circuit in Ensley Branch and Engineering Contractors and the Ninth Circuit in Coral Construction relied upon the Supreme Court's holding in Califano v. Webster. ${ }^{214}$ In Webster, the Court upheld a gender preference in the calculation of Social Security retirement benefits, observing that the purpose of the plan was to redress "society's long-standing disparate treatment of women," and that the "[r]eduction of the disparity in economic condition between men and women caused by the long history of discrimination against women has been recognized as such an important governmental objective."2215

212. See supra note 69 and accompanying text. Of course, because remedying discrimination by the governmental entity implementing the program is permissible under strict scrutiny, such a justification would also be permissible under the less demanding "exceedingly persuasive justification" standard.

213. See id.

214. 430 U.S. 313 (1977). See Engineering Contractors, 122 F.3d at 908-09; Ensley Branch, NAACP v. Seibels, 31 F.3d 154, 1579 (11th Cir. 1994); Coral Constr. Co. v. King County, 941 F.2d 910, 932 (9th Cir. 1991).

215. Webster, 430 U.S. at 317 (citation omitted). 
Virginia endorses relying on societal discrimination to justify an affirmative action program under the "exceedingly persuasive justification" standard. Relying upon Webster, the Court detailed the permissible uses of gender-based classifications, noting that these classifications could be used to compensate women for "particular economic disabilities [they have] suffered."216 Moreover, the Court noted that gender classifications could be used to "promote equal employment opportunity."217 There is no mention in this section of government culpability in these contexts, and there does not appear to be any reason to engraft such a requirement onto the "exceedingly persuasive justification" standard. Thus, even under Virginia's more demanding standard, instances of specific government discrimination are not required to justify a genderbased affirmative action plan.

\section{b. The Relevant Economic Sphere}

Even under traditional intermediate scrutiny, there was a limitation on attempts to remedy societal discrimination through gender classifications-the societal discrimination had to occur in the relevant economic sphere. ${ }^{218}$ The circuit courts that have recognized this limitation rely on Hogan, ${ }^{219}$ which in striking down an all-female nursing program because the state had failed to show "that women lacked opportunitics" in the field of nursing, ${ }^{220}$ recognized that "a State can evoke a compensatory purpose to justify an otherwise discriminatory classification only if members of the gender benefited by the classification actually suffer a disadvantage related to the classification."221

While the Virginia Court did not have the opportunity to address explicitly whether societal discrimination had to take place in the relevant economic sphere, this restriction undoubtedly remains a requirement under the stricter "exceedingly persuasive justification" standard. Clearly, the fact that Virginia prescribes a more demanding standard dictates that it should not be easier for the state to assert a permissible governmental interest than it was under traditional intermediate scrutiny. This notion is supported by the fact that Virginia allows gender classifications to compensate women for "particular economic

216. United States v. Virginia, 116 S. Ct. 2264, 2276 (1996) (quoting Webster, 430 U.S. at 320).

217. Id. (quoting California Federal Savings and Loan Ass'n v. Guerra, 479 U.S. 272, 289 (1987)).

218. See supra note 69 and accompanying text.

219. See Ensley Branch, 31 F.3d at 1580; Coral Constr., 941 F.2d at 932 . Engineering Contractors follows the conclusion in Ensley Branch, but does not specifically mention Hogan. See Engincering Contractors Ass'n v. Metropolitan Dade County, 122 F.3d 895, 909 (11th Cir. 1997), cert. denied, 118 S. Ct. 1186 (1998) (citing Ensley Branch, 31 F.3d at 1580).

220. Mississippi Univ. for Women v. Hogan, 458 U.S. 718, 729 (1982).

221. Id. at 728 . 
disabilities," general does not represent a permissible governmental interest. In addition, Virginia's repeated endorsement of Hogan indicates that Hogan's requirement that beneficiaries of a remedial statute must have suffered a previous disadvantage relating to the present classification ${ }^{223}$ remains intact. Indeed, Virginia notes that it is "[p]ursuing a similar inquiry" to Hogan's finding that there was no close resemblance between the alleged objective ("compensat[ing] for discrimination against women"), and the actual purpose underlying the discriminatory classification. ${ }^{224}$ Therefore, while remedying societal discrimination remains a permissible objective under the "exceedingly persuasive justification" standard, the requirement that this discrimination adversely impacted the group in the economic sphere targeted by the affirmative action plan remains in place as well.

\section{c. The Scope of the Relevant Economic Sphere}

While the justification of societal discrimination has been limited by the requirement that the discrimination must affect the relevant economic sphere, this restriction often had little practical effect under intermediate scrutiny. For example, the Ninth Circuit in Coral Construction found that evidence of discrimination in the construction industry supported an affirmative action program favoring women in all industries contracting with the county. ${ }^{225}$ While it may be convenient to institute an affirmative action program which applies to a broad range of separate public entities without breaking down the plan to examine whether the remedial action is justified with regard to every affected entity, this approach should be impermissible under the "exceedingly persuasive justification" standard. Broad programs affecting all industries contracting with a county address general economic disadvantages, and run afoul of the Supreme Court's requirement that remedial programs compensate women for "particular economic disabilities [they have] suffered."'226 Therefore, in order to justify an affirmative action plan under the "exceedingly persuasive justification" standard, the

222. United States v. Virginia, 116 S. Ct. 2264, 2276 (1996) (quoting Califano v. Webster, 430 U.S. 313, 320 (1977)) (emphasis added). Compare this with the selection quoted in Engineering Contractors, Ensley Branch, and Coral Construction, which appears to indicate that mere general societal discrimination can serve as an important governmental interest. See supra note 215 and accompanying text.

223. See supra note 221 and accompanying text.

224. Virginia, 116 S. Ct. at 2277 (quoting Hogan, 458 U.S. at 727).

225. See Coral Constr. Co. v. King County, 941 F.2d 910, 932 (9th Cir. 1991); see also Associated Gen. Contractors v. City \& County of San Francisco, 813 F.2d 922, 940-42 (9th Cir. 1987). However, in examining an industry-specific ehallenge with regard to construction, Coral Construction allowed only evidence of discrimination within that industry. See Coral Constr., 941 F.2d at 932-33.

226. See Virginia, 116 S. Ct. at 2276 (quoting Webster, 430 U.S. at 320) (emphasis added). 
government must show that discrimination affected every industry covered by the plan. Thus, in Coral Construction, the evidence of discrimination in the construction industry could be used to support an affirmative action program for construction contracts, but could not support such a program for other industries contracting with the county. Virginia's more restrictive view of the relevant economic sphere is a significant effect of the "exceedingly persuasive justification" standard, and may severely handicap efforts to install wideranging programs in the future.

\section{Evidentiary Burden Required to Show a Permissible Government Interest: "Persuasive Evidence"}

When an appropriate governmental interest is asserted, the ultimate issue, under both strict and intermediate scrutiny, is the sufficiency of the evidence supporting the stated purpose of an affirmative action program. Because the "exceedingly persuasive justification" requirement is less demanding than strict scrutiny, it follows that less evidence is required to justify a gender-based program. Similarly, this standard requires more evidence than traditional intermediate scrutiny.

In Engineering Contractors, the Eleventh Circuit was correct in stating that "sufficiency-of-the-evidence standards may elude precise formulation. ${ }^{2227}$ However, Virginia did provide a label which, while still difficult to define without illustration in subsequent case law, may be preferable to the Third Circuit's "probative evidence"228 or the Eleventh Circuit's "sufficient probative evidence"229 standards developed to analyze evidence under intermediate scrutiny. The Virginia Court found "no persuasive evidence in th[e] record that VMI's maleonly admission policy is in furtherance of a state policy of diversity."230 Thus, Virginia seems to require persuasive evidence to support the stated government interest.

Using the Eleventh Circuit's method of examining dictionary definitions, ${ }^{231}$ Virginia's standard is significantly more demanding than the standards set forth by either the Third or the Eleventh Circuits. The Eleventh Circuit appeared to strengthen the Third Circuit's "probative evidence" standard by adding the word "sufficient." same dictionary it used to define probative ("tending to prove or contributing towards proof"), sufficient means "[a]dequate, enough, as

227. Engineering Contractors Ass'n v. Metropolitan Dade County, 122 F.3d 895, 910 (11th Cir. 1997), cert. denied, 118 S. Ct. 1186 (1998).

228. Contractors Ass'n v. City of Phila., 6 F.3d 990, 1010 (3d Cir. 1993).

229. Engineering Contractors, 122 F.3d at 910.

230. Virginia, 116 S. Ct. at 2279 (emphasis added).

231. See supra note 75 and accompanying text.

232. See Engineering Contractors, 122 F.3d at 910. 
much as may be necessary ...."233 This dictionary defines "persuade" more strongly: "to bring oneself or another to belief, certainty or conviction."234 Therefore, Virginia has specifically increased the amount of evidence required to support the stated government interest under this formulation through its requirement of persuasive evidence.

While it is difficult to set forth a definition for the persuasive evidence standard, it is possible to delineate some general guidelines with regard to the weight accorded to different types of evidence. First, as with strict scrutiny, statistical evidence is the preferred method of proof under the persuasive evidence standard associated with an "exceedingly persuasive justification." Under both strict scrutiny and Virginia's new standard, the evidence offered in support of the government interest needs to show the effect of the alleged discrimination, whether it be the governmental discrimination required by strict scrutiny or the specific societal discrimination which may be offered to show an "exceedingly persuasive justification." The best way to do this is through the type of disparity index described by the court in Contractors Ass'n. ${ }^{235}$ Because gender-based affirmative action programs must be designed to compensate for particular economic disabilities, a showing of a gross disparity will normally not be enough. ${ }^{236}$ Therefore, a disparity index is particularly important because, as with strict scrutiny, it ensures that the relevant statistical pool of women is being considered. ${ }^{237}$

Similarly, in contrast to intermediate scrutiny, anecdotal evidence alone is unlikely to satisfy the persuasive evidence standard. Without support from statistical data, such evidence is subject to different interpretations and is of questionable validity. Therefore, while anecdotal

233. BlaCK's LaW Dictionary 1433 (6th ed. 1990).

234. Id. at 1144-45. Taking this logic a step further, it may be argued that "persuasive evidence" approaches or even exceeds the demands of the "strong basis in evidence" required by strict scrutiny. The dictionary definition of "strong" is "[c]ogent, powerful, forcible, forceful." Id. at 1423. However, any doubt created by this argument is erased by the contention that less evidence should be required to satisfy a standard less exacting than strict scrutiny.

235. See supra text accompanying note 58.

236. While gross statistical disparities may be enough to constitute prima facie proof of a pattern or practice of discrimination under Title Vll, when special qualifications are required to fill particular jobs, comparisons to the general population, rather than to the smaller group of individuals who possess the necessary qualifications, may have little probative value. See Hazelwood Sch. Dist. v. United States, 433 U.S. 299, 307-08 (1977). Thns, statistical comparisons with the general population are only helpful for certain entry-level positions or positions requiring minimal training. See City of Richmond v. J.A. Croson Company, 488 U.S. 469, 501 (1989). However, the genderbased affirmative action programs which have been analyzed by the lower courts have generally involved special qualifications such as owning a construction company. See, e.g., Engineering Contractors, 122 F.3d 895; Contractors Ass'n v. City of Phila., 6 F.3d 990 (3d Cir. 1993); Coral Constr. Co. v. King County, 941 F.2d 910 (9th Cir. 1991).

237. See Contractors Ass'n, 6 F.3d at 1005. 
evidence should be accepted and considered, it is best understood as "appropriate supplementary evidence."233

\section{Distinguishing the Demanding Evidentiary Burden of the "Exceedingly Persuasive Justification" Standard from \\ Strict Scrutiny}

While the persuasive evidence standard appears fairly demanding, it is still easier to satisfy than the strong basis in evidence required by strict scrutiny. The most obvious reason is that while the relative acceptability of statistical and anecdotal evidence is similar, less evidence is required to support a program under the "exceedingly persuasive justification" standard than under strict scrutiny. However, there is another significant distinction between these two standards. Because societal discrimination is accepted to support the government interest for affirmative action programs under the "exceedingly persuasive justification" standard, some evidence of discrimination that may justify such programs under Virginia's standard would be unacceptable under strict scrutiny. While evidence of private discrimination may be relevant under strict scrutiny analysis for the purposes of a passive participant justification, ${ }^{239}$ this evidence has to demonstrate a linkage between the government's awarding of public contracts, for example, and the discrimination that occurred in the private sector. ${ }^{240}$ In contrast, under the "exceedingly persuasive justification" standard, the defendant would likely be relieved of the difficult task of demonstrating such a linkage.

For example, strict scrutiny would require that consideration of a disparity index be limited to a comparison of the number of government contracts awarded to women to the number of women-owned businesses in the industry. However, under the "exceedingly persuasive justification" standard, the index could account for all contracts awarded to such businesses, and could use public contracts, private contracts, or both, without having to separate these numbers or inquire into the secondary effects of the government action. Another possible basis for showing such discrimination would be the failure rate of women-owned businesses compared to those owned by men in the same industry. ${ }^{241}$ Of course, all of this evidence could be supplemented with anecdotal evidence of discrimination by private and public entities.

238. Concrete Works v. City \& County of Denver, 36 F.3d 1513, 1521 (10th Cir. 1994).

239. See supra note 36.

240. See Concrete Works, 36 F.3d at 1529.

241. While this evidence could be rebutted by showing that the difference was caused by factors such as barriers to training, the burden of showing this would be shifted to the plaintiff. 


\section{4. "Persuasive Evidence" Applied: The Effect of the More Demanding Standard on the Coral Construction Decision}

The "persuasive evidence" standard may be illustrated by applying it to the evidence offered to support gender-based affirmative action plans in previous lower court opinions. The two most significant opinions on the sufficiency of evidence required to support gender-based affirmative action programs, Contractors Ass'n and Engineering Contractors, are unhelpful for the purposes of such an illustration. Since the evidence in both of these cases failed to meet even the intermediate scrutiny standard, it would also fail to be the persuasive evidence required of an "exceedingly persuasive justification." In contrast, in Coral Construction, the Ninth Circuit relied on a single twenty-two page affidavit of the president of a consulting engineering firm to find that a gender-based affirmative action program was justified by discrimination against women in the county's construction industry. ${ }^{242}$ The affidavit noted that between the years 1985 and 1987, less than seven percent of the firm's business came from private contracts, and that most of the firm's work resulted from gender-based set-asides. ${ }^{243}$ While the firm had tried to obtain more private contract work, it had been unsuccessful due to the "discriminatory attitude toward [the femal president] and towards women and minority businesses generally." "20244 In addition, the firm was the first woman-owned engineering firm in the state of Washington. ${ }^{245}$

While the Ninth Circuit found the affidavit enough evidence to satisfy intermediate scrutiny, this single affidavit falls far short of persuasive evidence. ${ }^{246}$ The evidence offered in Coral Construction was anecdotal, with no supplementary statistical evidence. However, an examination of the individual components of the affidavit described by the Ninth Circuit reveals what possibly could have justified the program under Virginia's heightened standard. For example, actual statistics which demonstrated that women-owned construction businesses' workload included a lower percentage of private contracts than did menowned construction businesses may persuasively indicate societal discrimination. As anecdotal evidence, the attribution of a lack of success to a discriminatory attitude would be insufficient. Virginia's new standard requires examples of this attitude as well as its effects, and more

242. See Coral Constr. Co. v. King County, 941 F.2d 910, $932-33$ (9th Cir. 1991).

243. See id. at 933.

244. Id.

245. See id.

246. Again, the court referred to two additional affidavits, which may have been taken under consideration as well, but there is no mention of these affidavits in the analysis. See id. at 917-18. 
affidavits containing similar information would strengthen the case as well.

\section{B. Showing a Close Relationship between the Government Interest and the Features of the Affirmative Action Plan}

The second prong of analysis under the "exceedingly persuasive justification" standard focuses on the relationship between the governmental interest and the proposed remedy. As set forth in Part I.D.2.b. above, the primary differences between intermediate and strict scrutiny appear to be that intermediate scrutiny does not require (1) that the government consider gender-neutral remedies before implementing an affirmative action plan; or (2) that numerical goals be tied to the proportion of qualified women. In addition, while the duration of a program is a relevant consideration under both standards, the lower level of scrutiny dictates that courts regard longer programs with greater tolerance under traditional intermediate scrutiny.

Virginia sheds little light on the relationship required between the goal and the means of accomplishing the goal under the "exceedingly persuasive justification" standard. The Eleventh Circuit also provides minimal support for its conclusions relating to strict scrutiny in this regard. This lack of authority makes it difficult to define or illustrate the requirements of the stricter standard in this context. However, because Virginia raises the standard of scrutiny, it is possible to make some educated guesses.

First, courts should require the consideration of alternative remedies for gender-based as well as race-based affirmative action. This is not a great burden, particularly in light of the fact that such remedies are generally analogous to the race-neutral remedies which need to be considered before implementing the race-based affirmative action plans that are often enacted simultaneously with gender-based programs. Second, the concerns underlying the relationship prong under strict scrutiny, such as the desire to benefit only those who are the true victims of discrimination and the concern about stigmatizing the group benefiting from the classification, apply to gender as well as race. However, because the governmental entity may be attempting to remedy societal discrimination, as opposed to its own discrimination, courts should analyze the conclusion that gender-neutral remedies will be ineffective and that gender-based affirmative action is therefore necessary with a less critical eye than they would for race-based programs, particularly given that race-based programs are subject to a higher level of scrutiny. Third, consideration of gender-neutral remedies does not require an actual attempt to implement these plans. This aspect of the "exceedingly persuasive justification" standard should demand only that such 
measures were considered, and that there was a legitimate basis for rejecting them. Fourth, the duration of the program should remain a relevant consideration, and the logical conclusion is that courts will allow programs to be longer under the "exceedingly persuasive justification" standard than they would under strict scrutiny, but will be more demanding than they would under intermediate scrutiny. Fifth, in terms of the link between the goals of a program and the proportion of qualified women in the field, the requirement that women be compensated only for particular economic disabilities mandates a close tie between the numerical goals of a gender-based program and the proportion of qualified women in the market. This stands in contrast to intermediate scrutiny, under which such a close relationship is not required. ${ }^{247}$ However, again, there would be more leeway associated with goals than under the strict scrutiny standard. An illustration of a goal that would fail strict scrutiny but would at least present a close case under the "exceedingly persuasive justification" standard is the affirmative action plan described in Engineering Contractors. ${ }^{248}$ The program targeted the construction industry and had a participation goal of $11 \%$, while the availability of bidders across three different categories of the construction industry was $3.2 \%, 6.9 \%$, and $13.3 \%{ }^{249}$ Waiver provisions were included in the program to make this goal flexible. ${ }^{250}$ While this relationship would be too loose to satisfy strict scrutiny, the goals and flexibility associated with this program were sufficiently related to the government interest that the program would probably satisfy the "exceedingly persuasive justification" standard.

\section{CONCLUSION}

The "exceedingly persuasive justification" standard associated with the Hogan-J.E.B.-Virginia progression represents the proper level of analysis for all gender-based classifications, including gender-based affirmative action. This standard is demanding, and many gender-based affirmative action plans that may have been permissible under intermediate scrutiny are no longer valid. However, such plans are not as difficult to justify as race-based programs. Under the "exceedingly persuasive justification" analysis, affirmative action plans must, at a minimum, attempt to remedy societal discrimination in the relevant economic sphere, and governments must provide "persuasive evidence"

247. See supra note 88 and accompanying text.

248. Again, Engineering Contractors stated that the goal did not need to be closely tied to the proportion of qualified women. While this premise is invalid under the exceedingly persuasive justification standard, the actual program at issue in that case may satisfy this stricter standard.

249. See Engineering Contractors Ass'n v. Metropolitan Dade County, 122 F.3d 895, 913, 929 (11th Cir. 1997), cert. denied, 118 S. Ct. 1186 (1998).

250. See id. at 929 . 
to support this interest. Moreover, these plans must be closely related to the stated interest of remedying such discrimination. This approach to gender-based affirmative action is firmly grounded in the Supreme Court's equal protection jurisprudence, and represents an opportunity to reconcile the circuit split associated with this important issue. 